Counting Scribes : Quantifying the Secularization of Medieval Book Production

\title{
Tahkokallio, Jaakko
}

2019

Tahkokallio , J 2019 , ' Counting Scribes : Quantifying the Secularization of Medieval Book

Production ' , Book History , vol. 22 , pp. 1-42 . https://doi.org/10.1353/bh.2019.0000

http://hdl.handle.net/10138/307213

https://doi.org/10.1353/bh.2019.0000

unspecified

acceptedVersion

Downloaded from Helda, University of Helsinki institutional repository.

This is an electronic reprint of the original article.

This reprint may differ from the original in pagination and typographic detail.

Please cite the original version. 


\section{Counting Scribes:}

\section{Quantifying the Secularization of Medieval Book Production}

\section{Jaakko Tahkokallio}

The mode of book production is one factor by which we judge the character of any literate society. The commercially produced printed book has been, and remains, a quintessential symbol of the modern era - of the Renaissance, the Reformation, mass literacy, and the democratization of knowledge. In contrast, medieval bookmaking was long seen as a predominantly monastic activity, emblematic of the power of the Church over information and thought, and indeed this idea still has wide currency among the general public.

Medievalists and specialists of the early printed book are of course well aware that the disparity between medieval and early modern book culture was not quite so stark. ${ }^{1}$ Several studies have demonstrated that the making of books became a largely commercial enterprise during the last medieval centuries, ${ }^{2}$ and in narratives about late medieval book culture the urban stationers, ateliers, scribes, and scriveners have come to hold something of a transitional position between the monastic early Middle Ages and the era of Gutenberg. Such narratives can be accused of teleologism, but there is no denying that the development of the movable type was a response to the greatly increasing demand for books.

While the urban professional bookmaking of the later Middle Ages has become a recognized and much-studied phenomenon, our overall understanding of the manuscript production taking place outside religious institutions remains nevertheless far from perfect. First, we do not have certain knowledge about the beginnings of urban production and its scale in relation to the output of religious institutions. ${ }^{3}$ The archival evidence brings bookmaking craftsmen to the fore soon after 1200, first in Paris and then in other cities, but the 
fact that a craft starts to leave archival traces at a certain point in time is hardly an argument for its absence before that date. Furthermore, records concerning all kinds of bookmaking remain so random throughout the Middle Ages that there is no hope of making quantitative comparisons to estimate the percentage of commercially produced books as a proportion of all those produced.

Besides the records, paleographical and codicological study of the surviving manuscripts has been used to access the world of late medieval nonmonastic books. In France, the beginnings of the professionalization of book decoration have been traced to the decades around the middle of the twelfth century and, starting from Paris around 1200, it is possible to identify books made by professional artisans on the basis of artistic style, since the practices of decoration and layout became notably uniform in the major urban centers of production. ${ }^{4}$ The stylistic criteria, however, are just as problematic as the documents. They let us identify books that were made by artisans on commission, but only for a particular type of production: properly commercial bookmaking, taking place in urban centers where the craft was organized and where the styles of individual craftsmen were governed by generally shared ideas about what was worth paying for, in short, by fashion. Consequently, it is not possible to assess noninstitutional manuscript production on stylistic grounds outside the few well-studied centers, such as Paris or Bologna. The same limitation applies even more forcefully to the period before the establishment of urban centers of production. Anecdotal evidence demonstrates that secular craftsmen were involved in bookmaking already in the eleventh century, but since such activity was not as organized as later on their work does not stand out stylistically as clearly as later urban production. ${ }^{5}$

In other words, only certain types of secularly produced books - those commissioned in late medieval urban centers - can be identified on the basis of their physical appearance. While we can be sure that noninstitutional ways of bookmaking were much more varied, we 
lack analytical tools for approaching such production. In fact, we do not even have a set language to discuss it. The words "commercial" and "professional", often used in the context of noninstitutional production, are ambiguous. "Commercial" implies that book production is taking place under market conditions and it also suggests (although does not necessitate) that those involved in the trade are making their living by it. "Professional", on the other hand, can carry the same connotations, but may also refer to the level of skill and specialization of the craftsmen involved. It is certain that while strictly speaking commercial book production, sometimes undertaken by men and women whose main profession was the making of books, was common in late medieval urban contexts, this was not the case before the thirteenth century. Also, during the last medieval centuries other ways of arranging the manufacture of books were common - quite possibly more common than commissioning books from specialist urban craftsmen. Manuscript bookmaking did not require large amounts of capital, and the minimally necessary skill of writing was common enough throughout the Middle Ages. That meant that any clerk, in every sense of the word, could double as a bookmaker, the quality of the product varying according to the skill of the scribe and the materials available. ${ }^{6}$ Furthermore, in a society which had imperfect markets for luxury commodities such as books, and in which exchange of gifts and favors was of great importance, many of the transactions involved in the processes of making and acquiring books were not strictly commercial. What about a bishop's scribe who, between writing charters and letters, copied a book for his dominus and received clothes, board, and a tacit promise of advancement? What about the village clerk who was paid by the local lord to copy a romance, even though he had never before done so? What about a student who copied a schooltext for his rich friend to make good his gambling debts? In none of these possible cases of noninstitutional production can the copying be called "professional" or "commercial", at least without qualifications. What is more, it is probable that much late medieval copying was done for personal use by 
the scribe, both in secular contexts and by mendicant friars. ${ }^{7}$ Finally, we know rather less than we would like about the sale and exchange of second-hand books and how their availability affected the making of new ones. ${ }^{8}$ As a consequence of our imperfect knowledge and the complicated nature of medieval exchange economy we must be wary of drawing a too simplistic and potentially teleological picture of a development from the world of monastic bookmaking to a commercialized one, even though this was without doubt one real trend in the history of the medieval book.

In this article, my goal is to propose a diagnostic tool for distinguishing all sorts of secular modes of making books from the production of religious institutions in corpora of manuscripts, and to present some preliminary observations on the chronology of what I call the secularization, rather than commercialization or professionalization, of bookmaking. To cut across the above-presented problems of categorization, I shall, for the purposes of the present inquiry, use the term "secular production" to refer to all book production taking place outside religious institutions, regardless of how precisely the copying was organized, paid for (or not), and undertaken. I am fully aware that this categorization, like all such, leaves some grey areas. The most important of these concerns religious institutions and outsourced scribal labor, a phenomenon well documented from the late eleventh century onwards. ${ }^{9}$ Here I would consider books commissioned entirely from lay professionals as secular production (whether the craftsmen worked at the premises of the monastery or elsewhere), whereas collaborative work between laymen and scribes in regular orders is more difficult to classify. However, in the data sets I am about to examine none of the manuscripts from religious institutions has been connected with a lay scribe, and thus this particular problem is irrelevant for the present study.

My main argument is a simple one. I suggest that the typical number of scribes copying a book (or more precisely, a codicological production unit) in a corpus of 
manuscripts gives indications about the setting in which the books were typically copied. ${ }^{10}$ The data examined suggests that in all secular contexts books were most commonly copied by a single scribe. As we shall see, for some sets of predominantly secularly produced manuscripts the proportion of single-scribe copies is as high as 90 percent. Secondly, a high proportion of copies made by multiple scribes collaborating within a single codicological production unit appears indicative of an institutional setting of production. In all the institutional contexts examined, the proportion of single-scribe copies is less than 50 percent. It needs to be immediately made clear that I am not suggesting that the number of scribes functions as a reliable diagnostic tool by which we can identify an individual manuscript as institutional or noninstitutional production. What I mean is that in large sets of manuscripts a high percentage of single-scribe copies suggests that many of these manuscripts were produced in secular contexts, whereas a high percentage of multiple-scribe copies indicates that many were produced at religious institutions. This argument, presented in the first part of the article, is based on quantitative examination of select manuscript corpora containing more than 1500 manuscripts, dating from c.750-c.1500.

In the second part of this article, I experiment with this method by applying it to the context in which large-scale secular bookmaking presumably started - the schools and universities. As we shall see, the percentage of single-scribe copies in the corpora of schooltexts examined rose consistently throughout the later Middle Ages, which is in harmony with the methodological hypothesis formulated in the first part. What is more, the rise in percentage was already apparent in manuscripts from the eleventh and twelfth centuries. These observations, while admittedly of very preliminary nature, suggest that secular bookmaking, known from anecdotal sources to have started at least from the eleventh century, may have been a commonplace phenomenon well before the birth of the universities and the organized guilds of bookmaking artisans. 


\section{Previous Scholarship and the Present Approach}

Since this article revolves around the collaboration of scribes I shall begin with an overview of how scribal collaboration has been previously studied and the assumptions made about its commonness in different contexts of book production. I shall then briefly introduce my own approach and the terminology I have used.

Existing scholarship on the extent of scribal collaboration is patchy, and this holds true for all different contexts in which books were produced over the Middle Ages. It has often been noted that collaboration between scribes was "common" in early medieval institutional scriptoria, ${ }^{11}$ but studies of scribal work in religious institutions usually concentrate on the style of handwriting and decoration and rarely give sustained attention to scribal collaboration as a phenomenon. ${ }^{12}$ When they do address collaboration, the focus tends to be on particularly intricate or peculiar forms of collaboration, e.g., between scribes and artists, between "master" and "student" scribes, ${ }^{13}$ between scribes from different cultural contexts, ${ }^{14}$

or the phenomenon of quire-by-quire copying. ${ }^{15}$ By contrast, little quantitative analysis has been made of scribes collaborating in institutional settings. ${ }^{16}$

As we come to the twelfth century, usually understood as the starting point of book production hors scriptorium, we find research devoted to collaboration between artists and scribes - indeed studies of this topic have been instrumental in making us aware of the fact that lay craftsmen were involved in bookmaking. ${ }^{17}$ At the same time, there is little work that explicitly addresses the frequency or patterns of collaboration between scribes in this context, and the few generalizations on the topic remain impressionistic. ${ }^{18}$

From the beginning of the thirteenth century and the documented takeoff of commercial book production in major cities, there is even more work on collaboration between various 
kinds of professionals - scribes, artists, bookbinders, and stationers. ${ }^{19}$ For this period, there is also scholarship addressing scribal collaboration explicitly, ${ }^{20}$ and in the debate concerning the late medieval London book trade, interpretations of its nature have played an important part. The debate is an instructive example, since it shows how the scholarly preference for studying individual manuscripts with intricate - but exceptional - patterns of collaboration may lead to mistaken conclusions on the nature of the book trade itself. The fact that one famous codex - the so-called Auchinleck Manuscript - was interpreted to show several scribes collaborating under the same roof led several scholars to assume that commercial book production in late medieval London happened in scriptorium-like workshops, a theory since discredited. $^{21}$

A somewhat similar effect can be seen in the case of quire-by-quire copying. Used as a technique to produce books quickly by dividing the exemplar between several scribes for simultaneous work, it is well attested starting in the Carolingian period. ${ }^{22}$ Problematically, however, some scholars have come to equate such a division of work with particularly efficient scriptorium organization, ${ }^{23}$ even suggesting a line of development in which this practice became more common over the thirteenth and fourteenth centuries as the production of manuscripts in university towns became more organized. ${ }^{24}$ Occasionally, the distinction between the "pecia method" of exemplar distribution and the "quire-by-quire method" of organizing the copying has also become blurred. ${ }^{25}$

Rather than concentrating on such exceptional cases, the present study looks for what was usual by casting the net wide over the whole of the Middle Ages and studying several samples of manuscripts. In what follows, I examine the numbers of scribes quantitatively, in three different data sets that seek to offer some coverage for the main contexts of book production over the Middle Ages: manuscripts from five institutional scriptoria (c.750 c.1200), manuscripts of seven vernacular texts (c.1200 - c.1500), and manuscripts of four 
school and university texts $(\mathrm{c} .800-\mathrm{c} .1500)$. The data sets are introduced as they make their appearances, and altogether they contain 1519 manuscripts.

The following methodological points should be kept in mind throughout. First, this study examines only the scribes responsible for the copying of the main text of a manuscript book. Thus, in all that follows, "scribes" refers to the "text scribes". All scribes who participated to the original copying of the text(s) of a single codicological unit have been included, even if they wrote just a few lines. ${ }^{26}$ In contrast, I have excluded scribes participating only to such stages of work that would have been easiest to do (and usually were done) once the main text was finished. This includes correcting, rubricating, decorating, adding musical notation, and also often copying of the possible gloss. Scribes working in the same codicological unit later on have been excluded, and several units later bound together into a single codex have been considered separately.

Second, with the exception of Sallust's histories, the data have been gathered from existing studies and catalogues, supplemented by occasional checking of individual manuscripts. This approach is admittedly not perfect, since it relies on the carefulness of the scholars who produced the source studies, in none of which was the counting of the text scribes the principal goal of the exercise. In a perfect world, a team of scholars would collect the data from original manuscripts and the interpretations of the numbers of hands would be double-checked, possibly in interplay with computational palaeographical methods. Hopefully something of this kind can be done in the future as a continuation of the present work. To achieve the main goal of the present article, which is to propose a new quantitative method of study, relying on published works is however the only viable option. Only in this way is it possible to examine a large sample of manuscripts across a wide spectrum of time and to lay out an argument for the potential of this line of approach. I shall come back to the 
methodological questions related to data reliability and work economy as I introduce the various corpora and in the conclusions.

To construe the data sets, I have used only such secondary works as report the number of scribes in a codicological unit with reasonable consistency. Even with these meticulous catalogues and studies, however, the level of precision varies when it comes to reporting large numbers of scribal hands. Some always state the precise figure, while others give up the precision (or at least are not consistent) when the number of hands is high. For this reason, I have discussed the number of scribes in three categories: one, two, or three or more. The reader should be aware that many of the manuscripts in the three-or-more category are reported as having multiple hands ("mehreren", "zahlreichen”, "molti” etc.).

Third, the number of hands appearing in a copy of a text bears some relation to the length of the text. It is a relevant question whether certain scriptoria display lesser numbers of hands per manuscript mainly because the manuscripts surviving from there happen to be shorter. As regards the scriptoria, I have calculated how the length of the manuscript correlates with the number of hands and reported the correlations when introducing the data sets. As one can expect, there is indeed a positive correlation - long texts are more likely to show several hands than short ones. These correlations are however relatively low and fairly similar in different contexts, and they cannot be the main explanation of the differences in the numbers of scribes seen in different settings of production. When examining the hands seen in the copies of a certain text, not products of a certain scriptorium, this check is of course not possible or meaningful.

Another related distorting factor is that fragmentarily surviving manuscripts have a high probability of showing just a single scribe. For instance, there is a slim likelihood of witnessing a change of hand on a single-folio fragment. In order to keep the focus on books and to eliminate distortion from data sets containing large quantities of very short texts, I 
have used a somewhat arbitrary limit of eight folios as my filter. If a codicological entity has more than this - i.e., more than the most common kind of single quire - I have counted it in. Nine folios may seem like a very short book, and indeed it is, but I have felt obliged to use a low limit since in some formats large quantities of text can be packed into a few folios. It should be added that in all the data sets the average length of books is much longer, and that in none of them has this exclusion of fragments and short entities meant excluding significant numbers of manuscripts, the numbers of which have been presented when introducing the corpora.

In much of the following, the main focus will be simply on whether we see one or several scribes working in a manuscript. However, when the data allow it, I have also looked at the patterns which the collaboration of scribes took. I have used three analytical categories to do this.

The first of these is that of quire-by-quire copying, i.e., copying so that each scribe writes only (or primarily) full quires. This procedure suggests that the exemplar was divided for simultaneous copying, presumably to hasten the production. This manner of distribution is often also evident from mistakes in the copying (text repeated or missing) and anomalies in quire structure. Manuscript catalogues tend to draw attention to this pattern of collaboration. It is very rarely encountered in the data.

The second and third categories are termed continuous and sequential collaboration, and their precise definitions depend one on another. In continuous collaboration, the scribal hands change back and forth in the manuscript relatively frequently, with a single hand making several appearances. In sequential collaboration, there are only few changes of the hand, each hand writes long stints, and a single hand does not make multiple appearances. There is naturally some room for interpretation in setting the boundary between these categories. To draw the line somewhere, I have used the following criterion: if one hand 
writes three or more stints, or at least two hands write two stints each, I have considered the collaboration continuous. These modalities of copying are distinguished because of the prima facie assumption that they may give us clues about the physical setting in which the scribes operated. Sequential collaboration could have come about in any setting (or series of settings). It is entirely conceivable that, for instance, a stationer first hired one scribe who produced, let us say, 70 folios of text and then passed it on to another scribe, who copied the next 40 folios finishing the text, simply because the original scribe was no longer available for any number of reasons. In other words, we do not need to suppose that the scribes resided or worked in the same premises for this to happen. However, continuous collaboration would have been difficult to arrange unless the scribes worked in the same physical setting. ${ }^{27}$ Such a setting could occasionally have been a household, but most often it is likely to have been an ecclesiastical institution of some kind. This information on the pattern of collaboration thus seems potentially valuable in identifying institutionally produced manuscripts.

\section{Comparing Institutional and Secular Production}

I shall start by examining five institutional settings for book production active over varying periods before year 1200. The following institutions have been chosen, first, because enough manuscripts have been identified as originating from them to make a tentative statistical examination meaningful and, second, because they are covered by a study that allows a look at the number of scribes witnessed in the surviving body of manuscripts. As regards the reliability of these sources of data, it should be noted that they were all written by scholars whose main interests are or were palaeographical and codicological. 
1. St. Gall (Benedictine, Canton of St. Gall), c.750-c.850: The data on St. Gall derive from the studies of Albert Brückner, whose descriptions differentiate between the scribes and various codicological elements with great precision. He divided the production of St. Gall into different stages, and here I have considered the codicological units dated to between c. $750-$ c. $850{ }^{28}$ There are 99 units for which enough information on the scribes is supplied, and their average length is 123 folios. ${ }^{29}$ The correlation between the number of scribes and the length of the manuscript is 0.18 ( 1 would be perfect correlation and 0 no correlation at all). In other words, the longer manuscripts are somewhat more likely to show multiple hands, but the connection is not very strong.

2. Freising (cathedral chapter, Bavaria), c.750-c.900: The scriptorium attached to the cathedral of Freising was subject of detailed examination in Bernhard Bischoff's Südostdeutschen Schreibschülen, one of the great classics of palaeographical scholarship. In this study, Freising cathedral is the institution with the largest number of surviving and identified manuscripts. ${ }^{30}$ Excluding the fragments, there are 95 codicological units, measuring on average 158 folios. ${ }^{31}$ The correlation between the number of scribes and number of folios is 0.22 .

\section{Moissac (Benedictine, then reformed Cluniac from the mid-eleventh century, Midi-} Pyrénées), c.1000-c.1200: Moissac has been studied in admirable detail by Jean Dufour, whose published monograph on its scriptorium between the tenth and twelfth centuries was developed from his doctoral thesis undertaken at the École des Chartes. ${ }^{32}$ Since the number of tenth-century manuscripts is very low, I have excluded them and focused on the betterdocumented eleventh and twelfth centuries. I have omitted those manuscripts which Dufour identifies as not stemming, or probably not stemming, from Moissac. ${ }^{33}$ Furthermore, I have 
excluded two impressive libri memoriales, used by the monastery over a very long time and showing handwriting of 26 and 31 scribes because of their exceptional nature. ${ }^{34}$ After these omissions, and that of the fragments, ${ }^{35}$ the corpus for Moissac consists of 63 codicological units which divide almost equally between the eleventh and twelfth centuries, with the average length of 159 folios. The correlation between manuscript length and number of scribes is 0.15 .

4. Salisbury (cathedral chapter, Wiltshire): The early production of the cathedral canons, working principally to furnish their own library, has been studied in meticulous detail by Teresa Webber for the period $1075-1125 .^{36}$ The Salisbury manuscripts, numbering 92 after the omission of fragments, ${ }^{37}$ are shorter than those from the above institutions, with the average length of 84 folios. The correlation between manuscript length and the number of scribes is 0.36 - significantly higher than in the other institutions.

5. Aldersbach (Cistercian, Bavaria), examined here for c.1150-c.1200: The first half century of the Cistercian house of Aldersbach, founded in $1146,{ }^{38}$ has been studied in detail by Donatella Frioli. ${ }^{39}$ The average length of a book in this corpus, consisting of 54 manuscripts, is 134 folios. ${ }^{40}$ There is almost no correlation between the length of the manuscript and the number of scribes involved (0.04). 


\begin{tabular}{|l|c|c|c|c|}
\hline & 1 scribe & 2 scribes & $3+$ scribes & N of MSS \\
\hline St Gall, c.750-c.850 & $47 \%$ & $13 \%$ & $40 \%$ & 99 \\
\hline Freising, c.750-c.900 & $34 \%$ & $21 \%$ & $45 \%$ & 95 \\
\hline Moissac, c.950-c.1200 & $21 \%$ & $21 \%$ & $58 \%$ & 64 \\
\hline Salisbury, c.1075-c.1125 & $36 \%$ & $20 \%$ & $44 \%$ & 92 \\
\hline Aldersbach, 1146-c.1200 & $42 \%$ & $16 \%$ & $42 \%$ & 54 \\
\hline
\end{tabular}

Table 1. Scribal collaboration in the institutional settings for book production

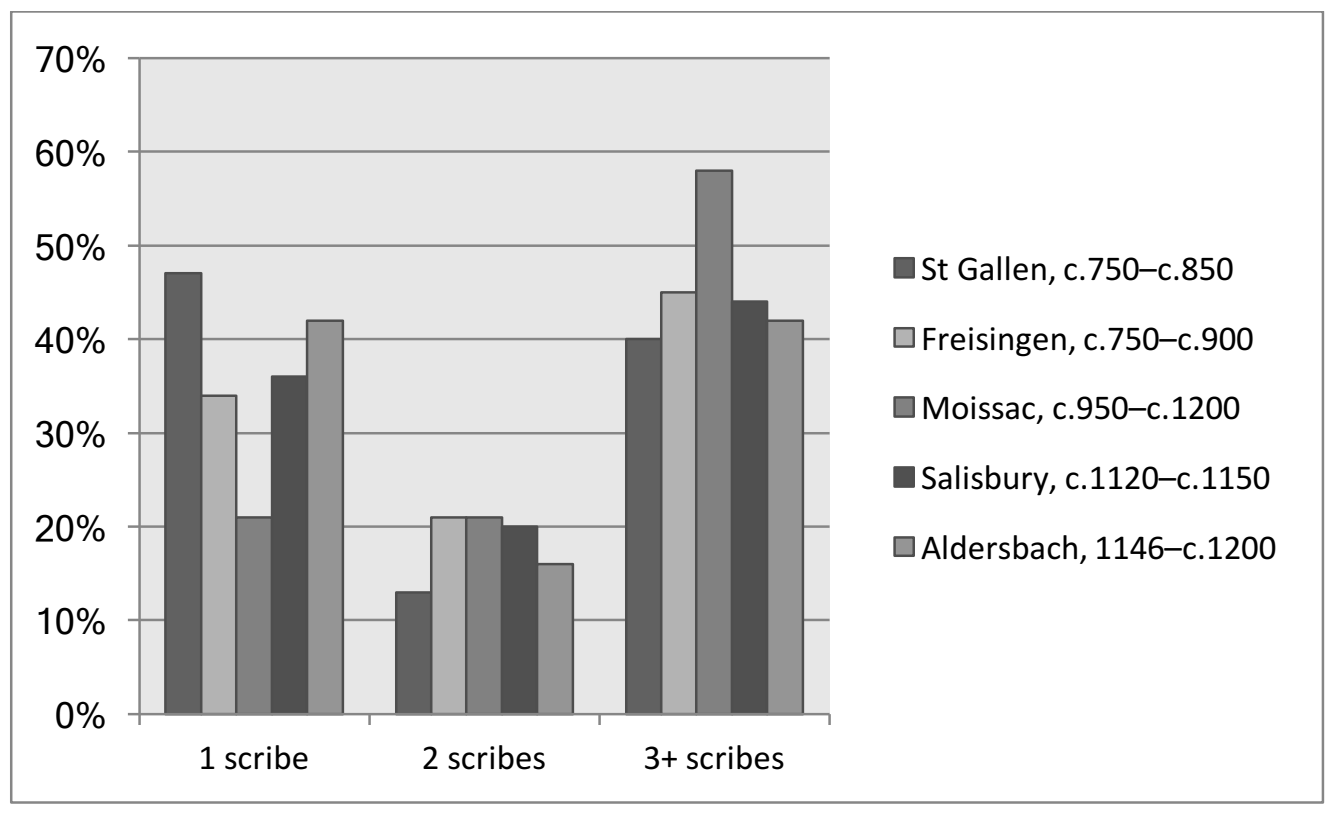

Figure 1. Scribal collaboration in the institutional settings for book production

Table 1 and Figure 1 point out certain unifying features across these centers. In all of them, at least three scribes participated into the copying of the text in 40 percent or more of the manuscripts, and nowhere do single-scribe copies make up more than 47 percent of the 
corpus. The relative similarity of these figures will become even more evident later when we set them against those stemming from other contexts of production.

However, the differences between these centers also deserve attention, and their analysis may help us to estimate the limits of validity of these generalizations. Firstly, let us consider the data from early medieval St. Gall, with its relatively high proportion of singlescribe copies of 47 percent. If we divide the sample into two chronological subsets, we see that in the ninth century this proportion rose as high as 50 percent (Table 2).

\begin{tabular}{|l|c|c|c|c|}
\hline & 1 scribe & 2 scribes & $3+$ scribes & N of MSS \\
\hline St Gall, c.750-c.800 & $43 \%$ & $17 \%$ & $40 \%$ & 35 \\
\hline St Gall, c.800-c.850 & $50 \%$ & $11 \%$ & $39 \%$ & 64 \\
\hline
\end{tabular}

Efforts of a single man largely account for this rise. The hand of Wolfcoz has been identified in 12 manuscripts, of which he copied eight completely on his own. To compare, the most prolific scribe of the earlier period, Winthar, copied just 3 (or possibly 4) books. The increase in single-scribe copying in St. Gall may thus be linked to just one highly skilled and active scribe, working over a long period. This observation should alert us to the possibility that a few scribes may have a big effect on the outlook of the production of a scriptorium, and that the proportion of single-scribe copies may in such situations be relatively high.

Indeed, it has been argued that monastic scriptoria were occasionally dominated by a small number of highly skilled scribes. Michael Gullick has described such circumstances in the twelfth-century scriptoria of Michaelsberg (Bamberg), Fécamp (Normandy), and Rochester (Kent). Gullick states that in these scriptoria a large proportion of production consisted of single-scribe copies. ${ }^{41}$ However, while there is no doubt that few scribes could dominate a scriptorium, I am doubtful whether single-scribe copies typically made up the 
majority of the production even in such circumstances. At least this was not the case in any of the five institutional settings examined above. Furthermore, the only set of quantitative data that Gullick presents comes from one scriptorium, that of Michaelsberg, and a closer examination of the evidence indicates that it cannot be taken at face value in this respect.

The suggestion that books were typically copied by a single scribe at Michaelsberg is based on a twelfth-century list from the library. This exceptional list reports books copied by specific named scribes. ${ }^{42}$ It contains no fewer than 145 items, each presented as the work of a single monk. There is however reason to doubt whether such books in reality contained only the handwriting of a single person. Seven of the books mentioned on the list are known to have survived, ${ }^{43}$ and only three of them are actually by a single scribe. In others, the named person was indeed the main scribe, but others participated into the copying as well. Moreover, if we look at all the surviving eleventh- and twelfth-century manuscripts from Michaelsberg - most of which do not figure on the aforesaid lists -we see that the proportion of single-scribe manuscripts is 33 percent and that three or more scribes participated in 48 percent. ${ }^{44}$ In other words, at least over a longer timespan, the scriptorium appears similar to the other institutions examined above in terms of scribal collaboration. Presence of skillful and motivated individuals could increase the proportion of single-scribe copies in the production, within certain limits. Perhaps we could speak of professionalization of copying within the monastery or other institution.

At the same time, in other institutions collectivity of scribal activity could be the norm. In our data, Moissac shows a high proportion of multiple scribes sharing the work on a book and a very low percentage of single-scribe copies. Here as well, we can see variation dividing the set into two chronological subdivisions. 


\begin{tabular}{|l|c|c|c|c|}
\hline & 1 scribe & 2 scribes & $3+$ scribes & N of MSS \\
\hline Moissac, $11^{\text {th }}$ century & $15,5 \%$ & $12,5 \%$ & $72 \%$ & 32 \\
\hline Moissac, $12^{\text {th }}$ century & $26 \%$ & $29 \%$ & $45 \%$ & 31 \\
\hline
\end{tabular}

Table 3. Scribal collaboration in Moissac

As shown in Table 3, in the eleventh century manuscript production was very much a collective activity, with the highest percentage of manuscripts copied by 3 or more scribes observed in any set of data. One may wonder whether this was because of the heavy liturgical duties of the Cluniac monks - according to Jean Dufour, the monks may have had only three hours a day available for copying. ${ }^{45}$

It is very much a possibility that collaboration was equally common in some other monasteries as well, but for the moment I have not been able to come up with data sets of comparable size from elsewhere that would show similar results. Note however the similarity of Moissac to the twelfth-century production of St. Mary Magdalene of Frankenthal (Aug., Rhineland-Palatinate), studied in detail by Aliza Cohen-Muslin, although the data set (Table 4) is very small. ${ }^{46}$

Finally, let us look at the patterns of collaboration in these institutional settings. Two of the studies, Webber's on Salisbury and Dufour's on Moissac, are relatively consistent in reporting the ways in which the scribal hands changed, and I have been able to consult manuscripts to check the changes of hands for some (although not all) books that are left unclear in the catalogues. 


\begin{tabular}{|l|c|c|c|c|}
\hline & 1 scribe & 2 scribes & $3+$ scribes & N of MSS \\
\hline St Mary Magdalene, & $17 \%$ & $22 \%$ & $61 \%$ & 18 \\
\hline Frankenthal, 12th century & & & & \\
\hline
\end{tabular}

Table 4. Scribal collaboration in St Mary Magdalene, Frankenthal

Finally, a few observations on the patterns of collaboration in these institutional settings. Two of the studies, Webber's on Salisbury and Dufour's on Moissac, are relatively consistent in reporting the ways in which the scribal hands change, and I have been able to consult manuscripts to check the changes of hands for some (although not all) books that are left unclear in the catalogues. Let us look at how the scribes collaborate in the multiple-scribe manuscripts from these centers: 


\begin{tabular}{|l|c|c|}
\hline Salisbury manuscripts with several scribes & $\mathrm{N}$ & $\%$ \\
\hline (N=59) & 33 & 56 \\
\hline continuous collaboration & 23 & 39 \\
\hline sequential collaboration & 3 & 5 \\
\hline
\end{tabular}

Table 5. Patterns of scribal collaboration in Salisbury

\begin{tabular}{|l|c|c|}
\hline Moissac manuscripts showing several & $\mathrm{N}$ & $\%$ \\
\hline scribes $(\mathrm{N}=55)$ & 21 & 38 \\
\hline continuous collaboration & 24 & 43 \\
\hline sequential collaboration & 10 & 18 \\
\hline unclear nature of collaboration & & \\
\hline
\end{tabular}

Table 6. Patterns of collaboration in Moissac

The collaboration in Salisbury (Table 5) seems to have been particularly tight, with scribes switching back and forth frequently, and indeed this was noted by Webber as well. ${ }^{47}$ She suggested that the participation of multiple scribes was a means to tackle haste: borrowed exemplars would have been available only for a limited period of time and, writing being hard work, collaboration would have made it possible to use more hours per day for copying them. The relatively high correlation between manuscript length and the number of scribes involved indeed supports this idea. The pressure of time certainly is one variable which would have affected the frequency of collaboration also in other settings. It would, for 
instance, be interesting to see whether works typically copied from exemplars owned by the institutions, such as perhaps liturgical books, were more often penned by a single scribe than works for which exemplars needed to be borrowed, but the present data do not make such examination possible.

In Moissac (Table 6), a slightly higher percentage of the manuscripts appears to be sequential work, with fewer changes of hand, but since there are so many unclear cases I do not see very much can be made out of these differences. What should however be noted is the absence of dividing the exemplum into quires for simultaneous copying.

We have seen some variation amongst the institutions and several variables certainly affected the frequency of scribal collaboration. These would have included the level of professionalization of the scribal activity, the amount of liturgical and other duties, and the time exemplars were available, to name but some. One may also wonder how patterns of manuscript survival affect the picture. For instance, would we see more single-scribe manuscripts if a bigger proportion of liturgical books (which were probably more often copied from in-house exemplars) would have survived?

Nevertheless, some concluding observations on the division of scribal work in the institutional settings are possible and their similarities appear to me more important than the differences. First of all, in no one of the documented data sets - or chronological subsets does the number of single-scribe copies rise above 50 percent. Looking at all the sets examined above, their average proportion is 36 percent. ${ }^{48}$ At the same time, the proportion of manuscripts copied by three or more scribes is typically over 40 percent. In four of the centers this percentage is between $40-45$, while the average proportion is slightly above this range, 46 percent, due to the higher frequency of multiple-scribe copying at Moissac. 


\section{Vernacular Bestsellers for the Laity, 1200-1450}

It is possible to examine the frequency of scribal collaboration in monastic and cathedral settings by looking at real historical institutions, thanks to decades of study dedicated to individual scriptoria and the relatively high survival rate of their output. Secular copying cannot however easily be assessed in the same way. According to present scholarly understanding, there were no secular "commercial scriptoria" even in late medieval cities. ${ }^{49}$ As regards the stationers who coordinated the production, we can connect substantial numbers of manuscripts only with a few of them, and even for those few, constructing relevant data sets on the scribes would involve substantial research into various studies, catalogues, and original manuscripts. ${ }^{50}$ Some studies identify significant numbers of manuscripts copied by particular scribes, but these identifications are largely based on colophons, which are probably inherently more likely to be encountered in single-scribe manuscripts than in ones in which the text scribes collaborated. ${ }^{51}$ Furthermore, the numbers of manuscripts connected to individual scribes are typically problematically low for quantitative examination. $^{52}$

For these reasons, I shall approach the secular end of medieval book production by looking at manuscripts of specific texts rather than production locations. I have sought for works fulfilling three selection criteria. Firstly, they must have been intended for lay readership. Secondly, they must survive in large numbers of copies. Thirdly, they need to have been studied in enough detail to make the examination of the numbers of scribes possible without consulting the manuscripts. Nonreligious vernacular bestsellers - works of Chrétien de Troyes, Dante, Boccaccio, Chaucer, Gower, and Lydgate - form a group that meets all these requirements particularly well. They reached a great popularity, and their later 
canonical or semicanonical status in various national literatures has ensured that the texts and their manuscripts have been thoroughly studied.

Existing scholarship on the audience of these vernacular texts, while in some cases disagreeing over details (i.e., whether they were written primarily for circulation in court circles, amongst the gentry, or urban merchants and clerks) shows a remarkably broad consensus that they were composed for mostly lay and certainly non-monastic audiences. ${ }^{53} \mathrm{~A}$ potential problem is of course that we cannot exclude the copying of these texts at religious institutions as well, and indeed there is evidence that this did occasionally happen. However, there are reasons to think that this was very rare. First, existing detailed studies on the manuscripts of these texts suggest this. Some of them provide very precise data about the circumstances of production. Marco Cursi's work on the Decameron is the most impressive in this respect, containing a well-founded analysis of the probable origin for every copy. Out of the fifty-two manuscripts, he suggests that only one was produced at a monastery, and finds the origin of one other unclear. ${ }^{54}$ All the others stem, according to him, from secular contexts. In the case of Chrétien de Troyes, monastic origin - or indeed even early provenance - has not been proposed for a single one of the thirty surviving more or less whole manuscripts. While we only have reliable information on their former owners starting in the fifteenth century, it is worth noting that by then the copies of Chrétien were mostly in private hands, usually belonging to noble families. ${ }^{55}$ We cannot absolutely exclude the monastic origin for some of these manuscripts, but this dearth of positive identifications is significant, considering the amount of study that these manuscripts have been subjected to.

Second, monastic library catalogues contained throughout the Middle Ages very few nonreligious vernacular works. For instance, the most extensive British catalogue -- created at St. Augustine's, Canterbury in 1375-1425 and meticulously edited in the Corpus of British Medieval Library Catalogues (as BA1) -- mentions 1777 different books. ${ }^{56}$ Forty-three of 
them contained texts in French, and two in Middle English. ${ }^{57}$ Out of the forty-three French books, twenty-eight were religious, historical, or scientific. Seventeen books - less than 1 percent of the whole collection - contained texts that can be described as romances, and seven of them came in a single donation, by Thomas Arnold. ${ }^{58}$ Other vernacular books most likely had similar origins, having belonged to collections of individuals before their entry to the monastery. Given that monastic library catalogues hardly ever give us all the books present in any institution, their testimony is of course only partial. ${ }^{59}$ Liturgical books kept in the sacristy are usually absent from the catalogues, and individual monks, abbots, and priors in particular may have in practice had books in their own possession. Nevertheless, the nearcomplete absence of vernacular works of secular subject matter from the main catalogues indicates that such texts did not belong to the official literary culture of monasteries. ${ }^{60}$

To sum up, while it is impossible to exclude the monastic origin of individual copies of these vernacular classics, it is difficult to come up with any other group of texts that would be more likely to have been excluded from large-scale institutional copying. Secular vernacular literature had no place in the program of communal reading in monasteries nor was it suited for private study. While individual monks and nuns must have been just as fascinated by these works as many laymen, and some probably procured copies for their own use, their reproduction cannot have been an institutional project. ${ }^{61}$

Regarding the sources for the scribal data on these texts, it should be noted that the studies and catalogues used (discussed in detail below as the datasets are introduced) are by their palaeographical character slightly more varied than is the case regarding the institutional scriptoria, but appear nevertheless fairly reliable.

1. Chrétien de Troyes, Romances: The thorough two-volume catalogue Les Manuscrits de Chrétien de Troyes is the result of collaboration by a large group of leading scholars in the 
field. A potential problem lies in the fact that some of the manuscripts receive, in different chapters, what are in effect several descriptions by different scholars, and these descriptions are not entirely consistent, as has been pointed out by William Kibler and by David Hult. ${ }^{62}$ However, in their estimates of the numbers of scribal hands, these different scholars arrive at the same conclusions, a measure of the reliability of the source. ${ }^{63}$ The catalogue lists 43 manuscripts containing one or more of the romances, and of these 13 have been omitted here as fragments. The remaining corpus of 30 manuscripts consists of books dated to c. $1190-$ c.1350, with the bulk of evidence from the thirteenth century.

\section{Dante Alighieri, Commedia: Marisa Boschi Rotiroti's meticulous Codicologia} trecentesca della Commedia discusses almost all imaginable codicological aspects of the fourteenth-century manuscripts of Dante's classic. ${ }^{64}$ The catalogue part of the study indicates the number of hands participating in the copying consistently, although these figures are not subjected to discussion in the analytical section. ${ }^{65}$ There are 292 codicological units, of which 22 have been excluded as fragments, bringing the size of the sample to 270 .

3. Giovanni Boccaccio, Il Decameron: Marco Cursi's study of the Decameron is among the most meticulous data sources used in this article. It lists sixty copies, stemming from the end of the fourteenth and the fifteenth century, and always indicates the number of scribal hands with admirable precision and consistency. Fragments excluded, we are left with a body of 52 manuscripts.

\section{Geoffrey Chaucer, The Canterbury Tales; 5. John Gower, Confessio Amantis; 6. John} Lydgate, Troy Book; 7. John Lydgate, Fall of Princes: The data for all these Middle English texts comes from the statistical survey of Derek Pearsall and A. S. G. Edwards - the 
only one of this kind of which I am aware. ${ }^{66}$ Pearsall and Edwards drew their data from a number of catalogues and studies, their criteria overall being similar to the ones I have used. ${ }^{67}$ In the case of the Canterbury Tales, M. C. Seymour's Catalogue of Chaucer Manuscripts provides more detailed information on the division of the scribal work, although the quality of the data appears far from perfect. ${ }^{68}$ It should be noted that the numbers of scribes for Chaucer derive from Pearsall and Edwards, which again relies on the generally reliable descriptions of the Manly-Rickert edition. ${ }^{69}$ 


\begin{tabular}{|l|c|c|c|c|}
\hline & 1 scribe & 2 scribes & $3+$ scribes & N of MSS \\
\hline Chrétien de Troyes & $76,7 \%$ & $10,0 \%$ & $13,3 \%$ & 30 \\
\hline Dante, Commedia, s. xiv & $89,3 \%$ & $7,8 \%$ & $2,9 \%$ & 270 \\
\hline Boccaccio, The Decameron & $88,5 \%$ & $7,7 \%$ & $3,8 \%$ & 52 \\
\hline Chaucer, Canterbury Tales & $73,7 \%$ & $15,8 \%$ & $10,5 \%$ & 57 \\
\hline Gower, Confessio Amantis & $80,0 \%$ & $10,0 \%$ & $10,0 \%$ & 40 \\
\hline Lydgate, Troy Book & $84,2 \%$ & $15,8 \%$ & $0 \%$ & 19 \\
\hline Lydgate, Fall of Princes & $93,3 \%$ & $6,7 \%$ & $0 \%$ & 30 \\
\hline
\end{tabular}

Table 7. Scribal collaboration in late-medieval vernacular works

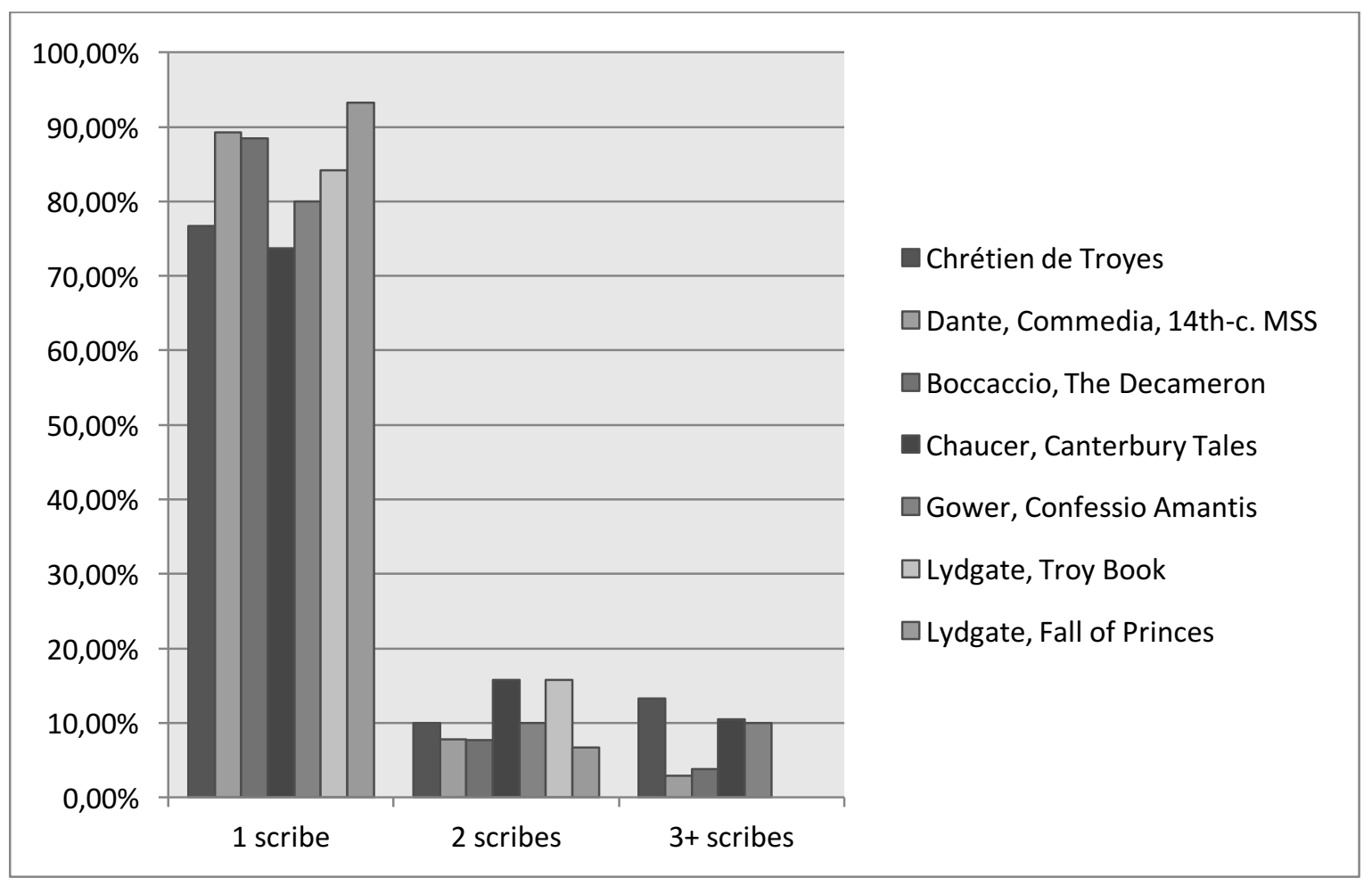

Figure 2. Scribal collaboration in late-medieval vernacular works 
Table 7 and Figure 2 bring together data from all these sources. The works are in roughly chronological order. The contrast of these data to those from the religious scriptoria is striking. As we can see, the overwhelming majority of the vernacular manuscripts were copied by a single scribe. There is some variation between the texts. With Chrétien de Troyes and Chaucer the proportion of collaboratively produced manuscripts is slightly higher than with the rest. At the same time, participation of several scribes was impressively rare in the copying of the Italian texts - especially the high proportion of single-scribe copies of Dante's Commedia, calculated from a very substantial number of manuscripts, deserves attention.

Since Cursi's catalogue of the Decameron is fastidious in recording how the scribes collaborated, it can reveal how the multiple scribe collaboration was organized. For the Decameron, the participation of several scribes was truly an exception - just six of the 52 copies show more than one hand. Three of these are instances of sequential copying, in which two scribes each copy a substantial portion of the work, with just one change. One is a case of supplementing the work of the paid scribe by the commissioner - a competent scribe himself who copied the first folio, perhaps to set the aesthetic standard, and also the last page. In just two manuscripts the hands work in continuous collaboration, switching back and forth. One of these was evidently produced at a monastery, while the origin of the other remains something of a mystery, although I cannot see why it could not be a copy made at some institutional context. ${ }^{70}$

Seymour's Catalogue provides a similarly detailed but less reliable analysis of the scribal hands of the Canterbury Tales. While it is in this case difficult to know how good the data actually are, it can nevertheless be observed that the reported patterns are similar to those seen in the Decameron, with the exception that several scribes participate in somewhat more manuscripts. Out of the fifteen copies showing more than one text scribe, eleven are clear 
cases of sequential collaboration, most commonly by two hands dividing the work into two substantial portions. ${ }^{71}$ Of the remaining four, only one appears like a clear case of simultaneous copying, with three scribes dividing the work neatly by quires. ${ }^{72}$ Three manuscripts show us hands working in continuous collaboration, one with three and two with two scribes. One of these manuscripts was demonstrably produced by a father and a son working together, probably on a commission. ${ }^{73}$ It has been suggested that the other was produced at a religious house, St. Mary de Pratis (Leicester), but this remains conjectural. ${ }^{74}$ The origin of one remains unknown. ${ }^{75}$ Even though this is admittedly a very small sample, it should be noted how few cases of continuous collaboration there are, and how these manuscripts have been attributed to a single household - usually a religious institutions. In contrast, by far the most common type of collaboration is the sequential work by two scribes.

Overall, the above figures derived from vernacular texts conform to, and for their part confirm, what has over the last decades become the scholarly consensus concerning late medieval commercial bookmaking. It was not undertaken in scriptorium-like workshops, where multiple scribes would have worked under the same roof. Rather, the standard procedure seems to have been to contract a single scribe to copy a text. Furthermore, resorting to simultaneous copying by dividing the exemplar for several scribes appears to have been exceedingly rare, presumably because of the practical difficulties involved, but possibly also because one skillful scribe ensured the maximal regularity of appearance indeed, contracts sometimes specify that a book was to be copied by one scribe. ${ }^{76}$

Tracking the Transition: Texts from Schools and Universities, c.800-c.1500

We have seen the contrast in the commonness of scribal collaboration between early and high medieval institutional production and late medieval copying for lay readers: in the 
institutional corpora, the average proportion of single-scribe copies is 36 percent, whereas it is 83 percent for the vernacular texts. The above data suggest that the percentage of singlescribe copies in a manuscript population may function as a proxy for the level of secularization of book making: the higher the proportion, the more prominent the noninstitutional modes of production.

Let us test this assumption in a preliminary way by looking at a group of school texts from the central and late Middle Ages. Traditionally, the development of book production as a market-oriented craft has been associated with the rise of the universities. If this is indeed the case, we should see changes in the patterns of scribal work observed in school texts over the central and late Middle Ages.

In this part of the study, the limitations of the available data are clearly more severe than in the previous ones, and hence its conclusions must be more tentative. Many popular school texts remain inadequately catalogued and studied because of the large numbers of surviving copies, and very few of the existing catalogues report the numbers of scribes accurately. I have however located three catalogues that give enough attention to scribes to make at least a suggestive examination possible, and supplied data on a fourth author from my own fieldwork.

1. Boethius, De consolatione Philosophiae: The early (pre-1200) manuscripts of Boethius have been subjected to detailed examination by Fabio Troncarelli. ${ }^{77}$ His work focuses on the palaeograpical and codicological analysis of the manuscripts and it appears comparable in precision to the studies of institutional scriptoria discussed above. Troncarelli lists 124 copies, and he provides information on the number of scribes for 100 of them. De consolatione was used in schools throughout the early and high Middle Ages. Even though its readership was not restricted to the classroom, its very widespread use in that context is 
evinced by textual sources on education from the ninth century onwards, ${ }^{78}$ the ninth- and tenth-century controversies over the scholarly use of the work, and the quantity of commentaries composed on it until the twelfth century. ${ }^{79}$

2. Sallust, Conspiratio Catilinae and Bellum Jugurthinum: Large-scale dissemination of Sallust's two histories started in the eleventh century. Their increased popularity reflected their adoption into the school curriculum, as the first major Latin prose texts besides Cicero's works. ${ }^{80}$ I have collected data on their manuscripts dated to c. $1000-$ c. 1200 from the original manuscripts. There are remains of 133 originally independent medieval books that contain one or both of them, of which 23 are fragments of eight or fewer folios. ${ }^{81}$ Of the remaining 110 books I have examined $51 .^{82}$

3. Aristotle Commentaries in Oxford libraries: Rodney Thomson's catalogue of copies of Aristotle commentaries in the libraries of Oxford offers accurate and consistent descriptions of their manuscripts. ${ }^{83}$ While the focus of this catalogue is, typically for university texts, on the contents of the manuscripts, Thomson's background is solidly in palaeographical and codicological scholarship and his experience in cataloguing manuscripts is vast, ${ }^{84}$ and it appears safe to assume that most of his judgements on the scribal hands are correct. Furthermore, since the corpus is comparatively large the numbers should even out the occasional mistakes better than, for instance, with the relatively small corpora surviving from various institutions. It also seems reasonable to assume that these texts were produced almost exclusively for use by university scholars. Many of the copies - especially those now in the Bodleian Library - came to Oxford after the Middle Ages, but a significant proportion of those belonging to the colleges were probably produced there. Thomson's catalogue lists 468 codicological units containing a commentary, of which 121 are too brief for inclusion, 
according to the standard I have set (93 are fragments, and 28 booklets of less than nine folios). Of the remaining, the information supplied about the scribes is too impressionistic in 44 cases (usually just the script, not number of hands is indicated). I have also excluded the twelfth-century manuscripts, since there are only seven short booklets (average length just 17 folios), and the five sixteenth-century copies, so as to make the subsets of each century more comparable to one another. This leaves us with 291 codicological units, average length 135 folios. The correlation between the length of the unit and the number of scribes is 0.27 .

\section{Manuscripts of Aristoteles latinus now in French libraries: To get a predominantly} continental corpus of similar size, I have used the manuscripts now in French libraries listed in George Lacombe's catalogue of Aristoteles latinus, a total of 411 manuscripts. ${ }^{85}$ It must be admitted that this is probably the most problematic data source of this study, even though his work was favorably received. Lacombe described a vast number of manuscripts and he must have worked relatively quickly. Furthermore, the main rationale for the catalogue was the establishment of the textual corpus of the Aristotelian texts, not palaeographical and codicological study of the manuscripts as such. Nevertheless, there are reasons to think that his observations on the scribes are of real value and that they deserve their place as one data source in this wider study. First, Lacombe had a solid palaeographical training, having been the first American scholar to graduate from the École des Chartes. He also contributed to E. A. Lowe's Codices Latini Antiquiores, probably the most prestigious and ambitious palaeographical project of the twentieth century. ${ }^{86}$ Second, he commented systematically on the number of scribal hands in his catalogue, suggesting that he consciously tried to formulate an opinion on each manuscript. Very probably Lacombe made mistakes, but it is also clear that his judgements were based on a high level of scholarly competence. As we shall see, the picture that his observations provide on the commonness of scribal collaboration in copies of 
university texts is rather similar to that provided by Thomson. This does not of course validate either data set but nevertheless suggests that we are seeing a real pattern. The Aristoteles latinus corpus also has the advantage of a relatively large size, which should compensate for its inherent inaccuracy to some extent. After excluding fragments and manuscripts for which the scribal data are not given in precise enough form, we are left with 381 codicological units. Their average length is 157 folios, and the correlation between unit length and the number of scribes is 0.1 .

Regarding the textual content of the corpus of copies of Latin translations of Aristotle, it should be noted that until the twelfth century only two of Aristotle's logical works, Categories and On Interpretation, were available, in Boethius's translation, and together with Boethius's commentaries they constituted the so-called logica vetus. ${ }^{87}$ In the twelfth century, Boethius's translations of the Prior Analytics, Topics, and Sophistici Elenci were recovered, and they came to be called the logica nova ${ }^{88}$ Finally, from the end of the twelfth century, a flood of other Aristotelian translations - including metaphysical, scientific, and moral works - entered the Latin Christendom. In this corpus, all the pre-twelfth-century copies contain texts of logica vetus and the twelfth-century manuscripts split evenly between logica vetus and logica nova. ${ }^{89}$ In the thirteenth century, the new texts take over and only four manuscripts (out of 231, i.e. 1.7 percent) contain only texts of logica vetus. Nevertheless, the context of use would have been similar for all these texts across all the centuries. They were employed principally in the schools, both before the beginnings of the universities as well as after their more formal establishment as set texts within the university curriculum.

Since the chronological coverage is different for each of these corpora, let us look at them one at a time, starting with the earliest, Boethius. In the whole corpus of the De consolatione manuscripts, c.800-c.1200, 47 percent of the copies are by a single scribe, 11 percent are copied by two, and 42 percent by three or more scribes. This does not look so 
different from the figures from religious institutions we just examined. However, if we divide the manuscripts by century (Table 8 and Figure 3) a very different - and rather interesting picture emerges.

\begin{tabular}{|l|c|c|c|c|}
\hline & 1 scribe & 2 scribes & $3+$ scribes & N of MSS \\
\hline 9th century & $28 \%$ & $6 \%$ & $66 \%$ & 18 \\
\hline 10 th century & $22 \%$ & $11 \%$ & $67 \%$ & 18 \\
\hline 11 th century & $60 \%$ & $6 \%$ & $34 \%$ & 35 \\
\hline 12 th century & $59 \%$ & $21 \%$ & $20 \%$ & 29 \\
\hline All & $47 \%$ & $11 \%$ & $42 \%$ & 100 \\
\hline
\end{tabular}

Table 8. Scribal collaboration in the manuscripts of Boethius's De consolatione Philosophiae, c.800-c.1200

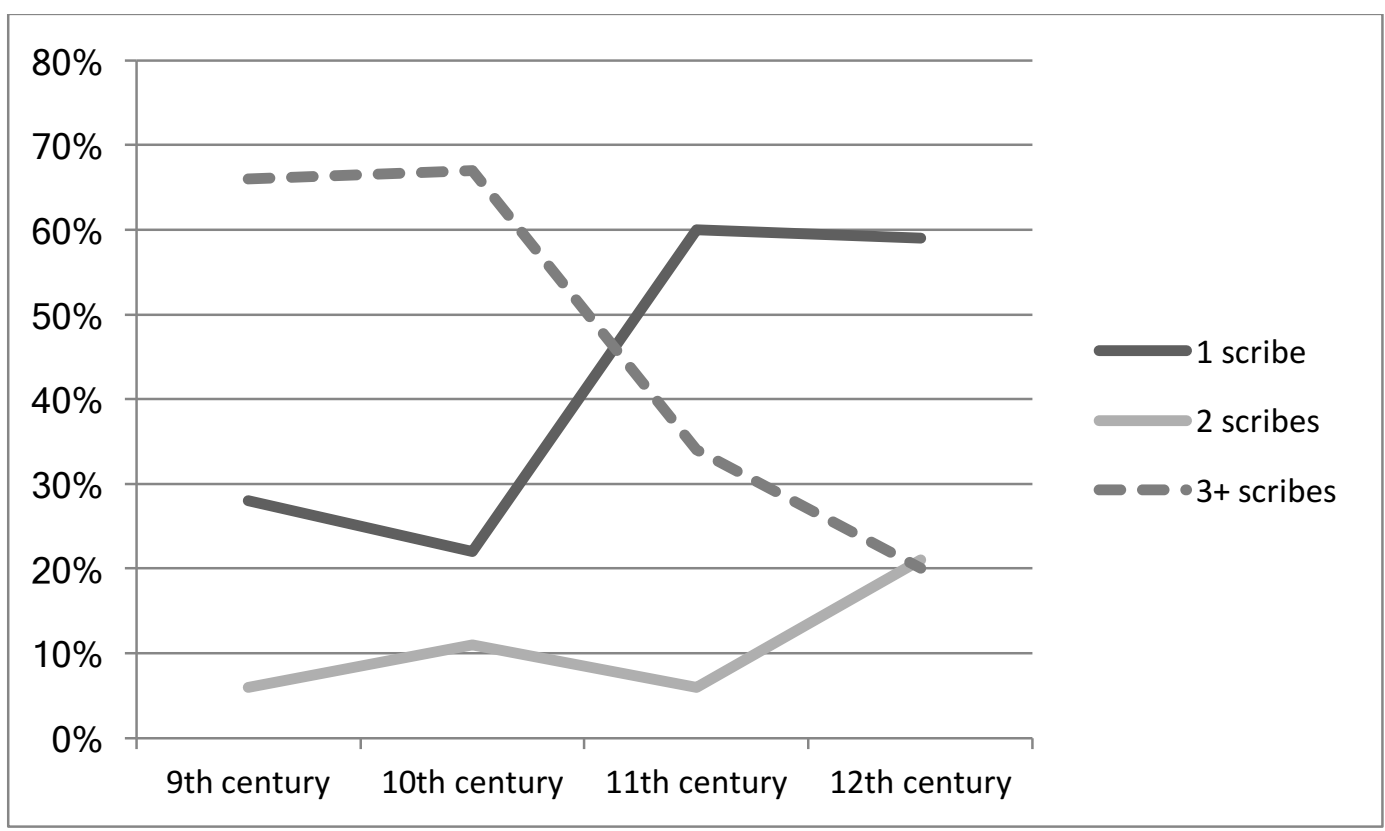

Figure 3. Scribal collaboration in the manuscripts of Boethius's De consolatione Philosophiae, c.800-c. 1200 
In the ninth and tenth centuries the number of single-scribe copies is fairly low (22-28 percent) while the number of copies produced by three or more scribes is high (66-67 percent). Indeed, these figures resemble those of institutional scriptoria, being closest to Moissac of the data sets examined above. It appears probable that most of these early copies stem from monastic scriptoria also because such a high proportion of the surviving manuscripts has been identified as monastic products: five of the ninth-century (28 percent) and eleven of the tenth-century (61 percent) manuscripts have been interpreted as probable or possible products of a specific monastic house.

In the eleventh and twelfth centuries the situation however turns on its head, with the proportion of single-scribe copies rising to about 60 percent, and the number of copies showing a large number of hands dropping to 34 percent in the eleventh century, and then to 20 percent in the twelfth. This kind of distribution is not seen in any of the institutional contexts examined above and, in the light of the evidence discussed in the first part of this article, it suggests that there was a change in how the texts were copied. It corresponds with a similar change in the available data on the known places of origin: just four of the eleventhcentury (11 percent) and four of the twelfth-century (14 percent) manuscripts have been attributed an institutional origin. This simultaneous change in patterns of scribal collaboration and origin information coincides chronologically with the rise of the cathedral schools and the beginning of the decline of monastery-based education.

Like Boethius's De consolatione, Sallust's Histories were also used as school texts, but unlike Boethius they appear to have had limited dissemination before c. 1000. Due to the low number of surviving copies from before this point in time (two from the ninth, five from the tenth), it is only meaningful to examine the eleventh and twelfth centuries (Table 9). 


\begin{tabular}{|c|c|c|c|c|}
\hline & 1 scribe & 2 scribes & $\begin{array}{c}3+ \\
\text { scribes }\end{array}$ & $\mathrm{N}$ of MSS \\
\hline 11th century & $47 \%$ & $26,5 \%$ & $26,5 \%$ & 15 \\
\hline 12th century & $61 \%$ & $19,5 \%$ & $19,5 \%$ & 36 \\
\hline All & $57 \%$ & $21,5 \%$ & $21,5 \%$ & 51 \\
\hline
\end{tabular}

Table 9. Scribal collaboration in the eleventh-and twelfth-century manuscripts containing one or both of Sallust's histories (Catilina and Jugurtha)

Here we see the percentage of single-scribe copies rising to a level comparable with that for Boethius in the twelfth century. In the eleventh-century manuscripts, the distribution of the numbers of scribes falls somewhere between figures typical for institutional and commercial production, but since these manuscripts make up a very small sample this does not allow strong conclusions.

With both these texts, there is another change in their codicology occurring simultaneously. At the same time that the number of scribes participating in the copying dropped, the proportion of small-format books rose (Table 10)..$^{90}$

\begin{tabular}{|l|l|l|}
\hline & Boethius & Sallust \\
\hline 11th century & $501 \mathrm{~cm}^{2}$ & $384 \mathrm{~cm}^{2}$ \\
\hline 12th century & $327 \mathrm{~cm}^{2}$ & $304 \mathrm{~cm}^{2}$ \\
\hline
\end{tabular}

Table 10. Average size of the page (in $\left.\mathrm{cm}^{2}\right)$ of the eleventh-and twelfth-century copies of Boethius and Sallust 


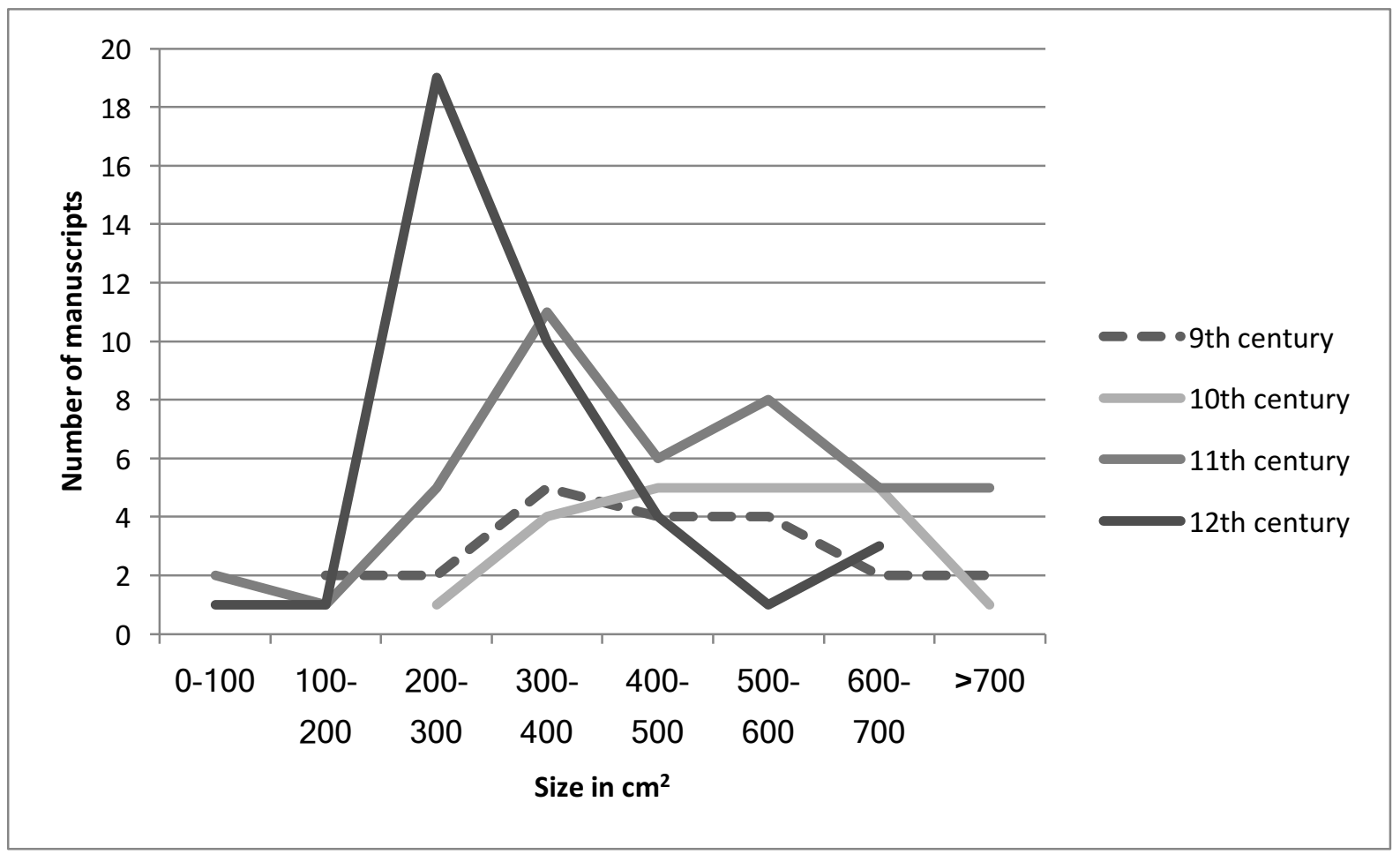

Figure 4. The size distribution of Boethius's De consolatione philosophiae across the period c.800-c. 1200 .

Figure 4, which plots the size distribution of the copies of Boethius brings the proliferation of small-format books to the fore particularly well. The change in size might be regarded as corresponding with the interpretation derived from patterns of scribal collaboration: namely an increase in the number of books produced for personal use, made by other means than institutional copying. I suspect that the increasing percentage of singlescribe copies in these corpora is explained both by copying for personal use and the commissioning of copies becoming more common, and that it reflects a change in the environment of their use - from the monastic to the cathedral school. ${ }^{91}$

Let us move on to the manuscripts of Latin translations of Aristotle, of which the bulk of the surviving copies dates from the period of the emergence of the universities onwards. Nevertheless, there is some chronological overlap with the corpora of Boethius and Sallust, 
even though the numbers of copies were low before the thirteenth century and the widespread circulation of new translations, as Table 11 and Figure 5 show us.

\begin{tabular}{|l|c|c|c|c|}
\hline & 1 scribe & 2 scribes & $3+$ scribes & N of MSS \\
\hline $10^{\text {th }}$ century & $38 \%$ & $12 \%$ & $50 \%$ & 8 \\
\hline $11^{\text {th }}$ century & $43 \%$ & $14 \%$ & $43 \%$ & 14 \\
\hline $12^{\text {th }}$ century & $60 \%$ & $0 \%$ & $40 \%$ & 15 \\
\hline $13^{\text {th }}$ century & $62 \%$ & $11 \%$ & $27 \%$ & 231 \\
\hline $14^{\text {th }}$ century & $60 \%$ & $12 \%$ & $28 \%$ & 98 \\
\hline $15^{\text {th }}$ century & $73 \%$ & $9 \%$ & $18 \%$ & 11 \\
\hline
\end{tabular}

Table 11. Scribal collaboration in the manuscripts of Latin translations of Aristotle, 10th15 th centuries

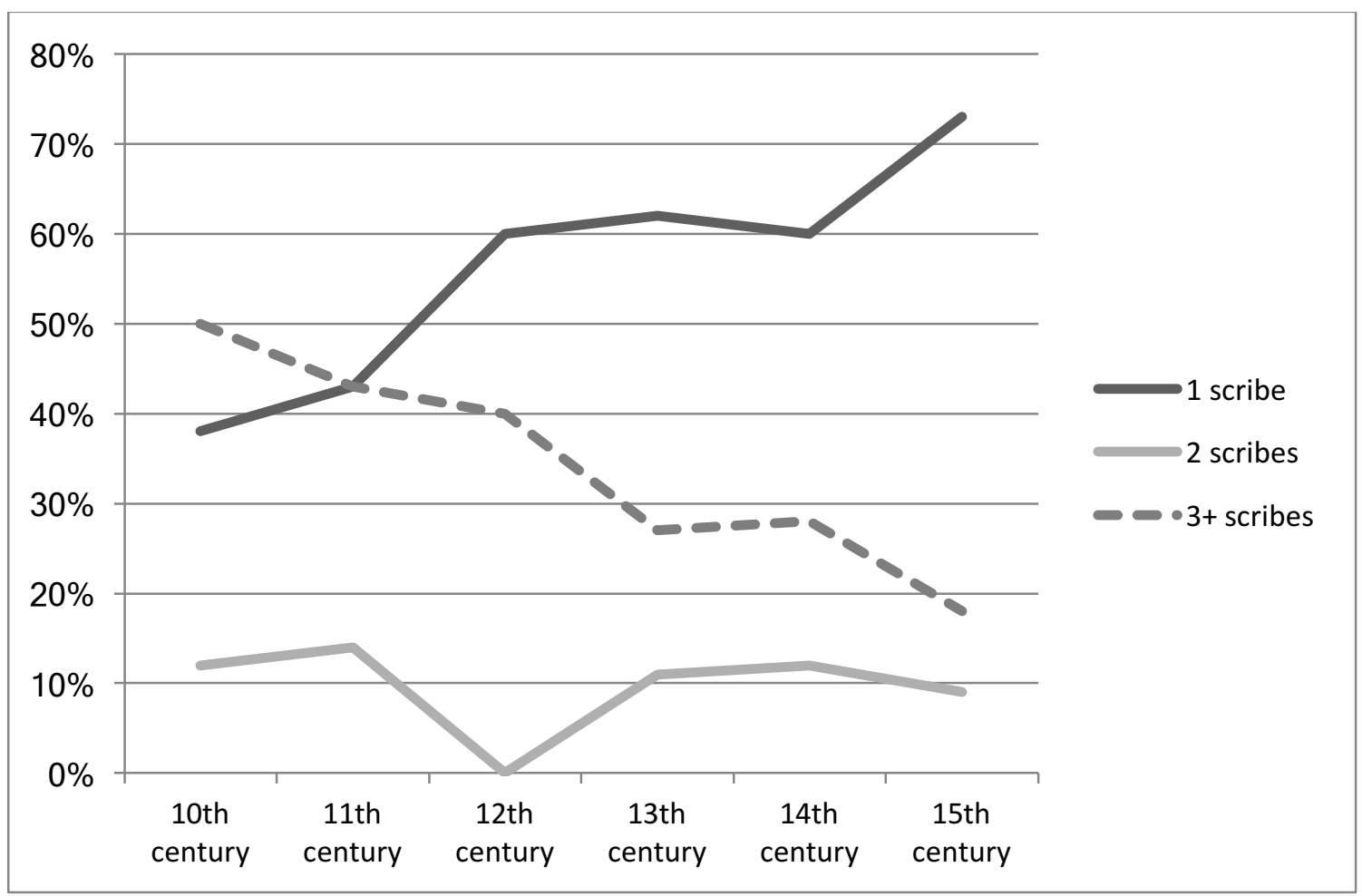

Figure 5. Scribal collaboration in the manuscripts of Latin translations of Aristotle, 10th15 th centuries 
Just as with Boethius, we see an increase in the percentage of single-scribe copies over time. In the large samples of surviving copies from the thirteenth and fourteenth centuries by far the most robust element of this dataset - single-scribe copies constitute precisely the same proportion of the manuscript population as they do with twelfth-century Boethius and Sallust, about 60 percent.

Finally, let us look at the Aristotle commentaries from Oxford libraries, which provide a large corpus, rather more evenly distributed between the thirteenth, fourteenth, and fifteenth centuries (Table 12).

\begin{tabular}{|l|c|c|c|c|}
\hline & 1 scribe & 2 scribes & $3+$ scribes & N of MSS \\
\hline $13^{\text {th }}$ century & $65 \%$ & $7 \%$ & $27 \%$ & 69 \\
\hline $14^{\text {th }}$ century & $70 \%$ & $10 \%$ & $20 \%$ & 86 \\
\hline $15^{\text {th }}$ century & $75 \%$ & $8 \%$ & $17 \%$ & 136 \\
\hline
\end{tabular}

Table 12. Scribal collaboration in the Aristotle commentaries in Oxford libraries, 13 th-15th centuries

As we see, the percentage of single-scribe copies from the thirteenth century is close to that of other school texts. However, it rises somewhat above the rest in the fourteenth century and approaches levels typical for vernacular books in the fifteenth.

Compared to works of secular vernacular literature, late medieval university texts are found more often in manuscripts in which several scribes collaborated. I would suggest that 
this is a result of the production often taking place in the context of an academic institution, such as a college: another kind of an institutional setting. ${ }^{92}$

However, the main trend, seen in the manuscripts of all these scholarly texts, is a steady increase in the percentage of single-scribe copies over time. The primary context in which such texts were used, coupled with the increasingly high percentage of single-scribe copies, together reinforce the hypothesis that when that percentage rises above 50 percent, it is indicative of a significant level of secularization, and probably also commercialization, of the processes of production.

\section{Conclusions}

On the basis of the data examined above, it appears that the proportion of single-scribe copies in a corpus of manuscripts stands in relation to how large a percentage of the corpus was produced in secular settings. This makes sense in the light of what we know about the organization of noninstitutional book production. Concerning bespoke bookmaking by contract, Malcolm Parkes has suggested that a single scribe was typically responsible for the copying of the main text, even though there was of course variability in the arrangements, depending on the availability of exemplars and scribes. ${ }^{93}$ The text and the purpose for which it was being copied determined the layout and the structure of the book, and the best option was to have one competent scribe to copy it first. Once the main text was fixed on the page and the quire structure set it was easy to involve other specialized artisans in the subsequent stages of production. Likewise, when manuscripts were copied for the scribe's own use this almost by definition meant single-scribe copying. Scribes were likely to collaborate on the writing of the main text only if they resided in the same premises and the copying was seen as a collective undertaking. It is conceivable that this may have happened occasionally (e.g., in 
aristocratic households), but the vast majority of the settings in which these conditions were met were, throughout the Middle Ages, religious institutions.

To prevent any misunderstanding, it is necessary to restate the obvious: the number of scribes working in the main text of a manuscript can never by itself tell us the kind of context in which that manuscript was made. As we have seen, single-scribe copies were written in all kinds of settings, and while it was apparently rare for several text scribes to copy books collaboratively in noninstitutional settings, this too happened occasionally. The limitations of the data should also be kept in mind. The corpora studied in this article comprise 1519 manuscripts. Considering the overall volume of surviving manuscripts from the Middle Ages in relation to the amount of data analyzed, it is obvious that my conclusions are to be confirmed, adjusted, or even proven wrong by further research. ${ }^{94}$ I have worked through certain sets of data with certain questions in mind, and I hope that other scholars will test my hypotheses, first with different sets of data, and second with a critical eye on the methodology I have used.

Nevertheless, one must conclude that the number of scribes appears a potentially powerful proxy when looking at large samples of manuscripts and trying to form an understanding of the cultural context in which they were produced. Michael Johnston and Michael Van Dussen have recently criticized what they have perceived as a contrast between the study of medieval manuscripts and the printed book. ${ }^{95}$ According to their interpretation, the "history of the [printed] book" has been about the book as a cultural, economic, and social phenomenon - about print culture - whereas manuscript scholarship tends to concentrate on individual manuscripts, small groups of books, or a single scriptorium. This generalization is not entirely justified. Manuscript scholars have been sensitive to the social and cultural significance of books as material objects even before historical bibliography developed into the modern history of the book, and this is especially true regarding the study of the early 
Middle Ages. ${ }^{96}$ The generalization also does injustice to the significant (largely continental) tradition of quantitative codicology ${ }^{97}$ and fails to take into account the analytical endeavors of several (often British) scholars, working with manuscripts in the fields of social and intellectual history. ${ }^{98}$

Nevertheless, even if exaggerated, Johnston's and Van Dussen's accusation is not entirely wrong either. Scholars working on medieval manuscripts often do concentrate on a relatively small number of books, and their efforts are not evenly divided, with a small number of famous manuscripts attracting a disproportionate quantity of attention and many others remaining more or less neglected. ${ }^{99}$ This happens for various, mostly good reasons. Art historians have contributed greatly to the study of medieval manuscripts, and if their focus has been on items of exceptional beauty and has helped turn some manuscripts into celebrities, this is a result of the paradigm of their academic discipline - and a largely positive one at that, not something to blame individual researchers about. Scholars working within various philological traditions have likewise had good textual reasons to study the Guiot manuscript of Chrétien de Troyes's romances or the Hegwrt Chaucer in great detail. ${ }^{100}$ And needless to say, all research involving or targeting manuscripts is time-consuming and requires a high level of specialization. Detailed catalogues and case studies have been - and will be - absolutely essential to the development of the field.

At the same time, I would urge that the challenge to generalize about medieval manuscript culture should be taken seriously. By consciously orienting towards social and cultural history, historians of the printed book have made its study relevant for a much larger audience than those with an interest in historical bibliography. A similar approach is called for if manuscript scholarship is to enhance its relevance within the wider field of historical studies. In generalizing, quantitative approaches will be essential. The rise of the digital humanities is reshaping the study of medieval manuscripts at the moment, 
with much work under way in digital palaeography, stemmatology, text-recognition of handwritten texts, and digital representation and markup of manuscripts. ${ }^{101}$ However, the digital turn will also enable more efficient exploitation of data existing in catalogues and case studies - hidden in plain sight, one could say. In this study, the data was created by typing manually into spreadsheets, and creating a machine-reading procedure to get to the same end would not have been time-saving, given the varying nature and languages of the catalogues and studies, the necessity of many case-by-case calls on how to convert a catalogue entry into a row in a spreadsheet, and the comparatively limited quantity of data handled. However, for creating larger corpora of comparable data machine-reading tools would be, or at least will soon be, enormously useful.

This kind of quantitative use of catalogue and case-study data presents its challenges, which parallel those encountered in digital or computational palaeography. Given that manuscript books are complicated artefacts and that there is more or less inherent uncertainty in every estimate considering many of its fundamental aspects (like dating, origin, number of scribes), Peter Stokes and others have emphasized that the crucial question in developing and using computational palaeographical tools is what level of accuracy we are satisfied with: "How near is near enough?" Indeed, the same question is present whenever human researchers make palaeographical and codicological judgements on the dating or geographical origin of a book, or the number of scribes appearing in it. ${ }^{102}$

In this article, I have used sources of data of which some appear inherently more trustworthy than others, but which, taken together, allow for revealing observations. My approach in the selection of the data sources has been somewhat eclectic, and I have privileged wide coverage - chronologically, geographically, socially and regarding the 
content of the manuscripts - over the homogeneity of the data sources. My own view and it is mostly an intuitive one - is that in quantitative surveys the most fruitful approach will often lie in this direction. That is not to say that due caution with the data sources would not be necessary, it certainly is. However, verifying every single fact (in this case, how many text scribes copy in one codicological unit) requires massive amounts of research time, and given the nature of the evidence even the "verified" data would not be free of mistakes. Time so spent will not necessarily pay off well in terms of research results, compared to what we can achieve by investing this same time in, for instance, creating new datasets from other secondary works. The more samples we have, the more these samples will help in controlling one another. In this study, for instance, the samples from each different context of production ("institutional", "secular", "scholarly") align well and create sensible patterns, without great outliers, which suggests that drawing real conclusions from the data is warranted. Likewise, the sheer quantity of data also helps in evening out inconsistencies in the data quality. In brief, in quantitative studies of medieval manuscripts we will need to keep in mind we are always working with samples and with imperfect data. This is the nature of quantitative scholarship in social sciences and biology as well - manuscripts are no different from populations of other real-world entities.

The main objective of this article has been to introduce and explore a new quantitative approach for the study of medieval book culture. At the same time, some of the preliminary observations presented may turn out to be of real importance for our understanding of how medieval manuscript culture developed, provided they receive further corroboration. Studies of particular manuscripts and anecdotal documentary evidence have suggested that paid hands were involved in book production already in the eleventh and early twelfth centuries. The preliminary quantitative analysis 
undertaken here suggests that these cases are probably by no means exceptional. Admittedly, the samples of copies of school texts from the high Middle Ages examined are not large, but they tell a remarkably consistent story. Secular, even if not primarily commercial, production of manuscripts may have been commonplace well before the universities and Paris bookshops, and possibly even before the widespread copying of glossed books of the Bible from the mid-twelfth century onwards. Jan Ziolkowski has suggested that the schools were catalyzing the book trade widely in twelfth century, with authorial awareness of what he calls a "textbook market". ${ }^{103}$ My observations accord with his suggestion and I suspect that the roots of the phenomenon may well lie in the environment of the eleventh-century cathedral schools. It may even be that this method could yield intriguing results in earlier periods as well. Perhaps it could be applied to testing the prevalent (and quite possibly correct) interpretation of Carolingian and Ottonian book production as predominantly a monastic (or at least institutional) affair. More quantitative work seeking to understand medieval book production in its social and economic contexts is needed, and the possibility of future discoveries that will alter our picture of medieval book culture quite substantially cannot be excluded.

\footnotetext{
${ }^{1}$ For bibliography on the topic, see Alexandra Walsham and Julia Crick, "Introduction: Script, Print and History," in The Uses of Script and Print, 1300-1700, ed. Julia C. Crick and Alexandra Walsham (Cambridge: Cambridge University Press, 2004).

${ }^{2}$ For Paris, see François Avril, “A quand remontent les premiers ateliers d'enlumineurs laïcs à Paris,” Les Dossiers de l'archéologie 16 (1976): 36-44; Alison Stones, "Secular Manuscript Illumination in France," in Medieval Manuscripts and Textual Criticism, ed. Christopher Kleinhenz (Chapel Hill: University of North Carolina Press, 1976), 83-102; Patrick M. de Winter, “Copistes, éditeurs et enlumineurs de la fin du XIVe siècle: la production à Paris de manuscrits à miniatures,” in Actes du Congrès national des sociétés savantes: Section d'archéologie et d'histoire de l'art (1978), 173-198; Richard Rouse and Mary Rouse, “The Book Trade
} 
at the University of Paris, ca. 1250-ca. 1350," in La Production du livre universitaire au moyen âge, ed. Louis J. Bataillon, Bertrand G. Guyot, and Richard H. Rouse (Paris: Centre national de la recherche scientifique, 1988), 41-114; Richard Rouse and Mary Rouse, Manuscripts and Their Makers: Commercial Book Producers in Medieval Paris, 1200-1500, 2 vols. (Turnhout: Brepols, 2000). For England, see M. A. Michael, "Urban Production of Manuscript Books and the Role of the University Towns," in The Cambridge History of the Book in Britain, vol. 2, 1100-1400, ed. Nigel J. Morgan and Rodney M. Thomson (Cambridge: Cambridge University Press, 2008), 168-194. For Italy, see, e.g., Alessandro Conti, La miniatura Bolognese, Scuole e Botteghe 12701340 (Bologna: ALFA, 1981); Armando Petrucci, “Il libro manoscritto," in Letteratura italiana, vol. 2, Produzione e consumo (Turin: Einaudi, 1983), 499-524; and id., "Storia e geografia delle culture scritte (dal secolo xi al secolo xviii)," in Letteratura italiana: Storia e geografia, vol. 2, part 2 (1988): 1195-1292.

${ }^{3}$ David D’Avray, Medieval Marriage Sermons (Oxford: Oxford University Press, 2001), vi-vii and 15-30, raises many open questions but does not supply quantitative answers to them.

${ }^{4}$ For the Parisian styles, see Robert Branner, Manuscript Painting in Paris during the Reign of Saint Louis: A Study of Styles (Berkeley: University of California Press, 1977); and Patricia Stirnemann, "Fils de la vierge: L'initiale à filigranes parisiennes: 1140-1340," Revue de l'Art 90 (1991): 58-73 and Christopher de Hamel, A History of Illuminated Manuscripts, 2nd ed. (London and New York: Phaidon, 1994), 118-23. For the beginnings of the "professional styles", see Patricia Stirnemann, "Où ont été fabriqués les livres de la glose ordinaire dans la première moitié du XIIe siècle?", in Le XIIe siècle: Mutations et renouveau en France dans la première moitié du XIIe siècle, ed. Françoise Gasparri (Paris: Cahiers du Léopard d'Or, 1994), 257-301.

${ }^{5}$ See, e.g., Michael Gullick, "Professional Scribes in Eleventh- and Twelfth-Century England," English Manuscript Studies, 1100-1700, 7 (1998): 1-24; Carl Nordenfalk, Codex Caesareus Upsaliensis (Stockholm: Almqvist \& Wiksell, 1971), 136-7 and 147-8 and Knut Berg, Studies in Tuscan Twelfth-century Illumination (Oslo: Universitetsforlaget, 1968), 205-20.

${ }^{6}$ For the commonness of basic literary skill in the early Middle Ages, see Rosamond McKitterick. The Carolingians and the Written Word (Cambridge: Cambridge University Press, 1989) and the articles in The Uses of Literacy in Early Medieval Europe, ed. Rosamond McKitterick (Cambridge: Cambridge University Press, 1990). For “provincial” Middle English book making, see Michael Johnston, "The Household and Literary Production in England, 1350-1500," in The Elite Household in England, 1100-1550, ed. C. M. Woolgar (Donington: Shaun Tyas, 2018), forthcoming.

${ }^{7}$ For mendicant book production, see D'Avray, Medieval Marriage Sermons, vii-viii and 25-26. 
${ }^{8}$ That the availability of second-hand books could have a significant effect on the production volume of new books is suggested by Eltjo Buringh, "Books Do Not Die: The Price of Information, Human Capital and the Black Death in the Long Fourteenth Century," CGEH Working Paper Series, no. 55, 2-26 (http://www.cgeh.nl/sites/default/files/WorkingPapers/cgehwp55_buringh.pdf).

${ }^{9}$ See Gullick, "Professional Scribes in Eleventh- and Twelfth-Century England," 1-24.

${ }^{10}$ For a useful codicological typology and the definition of a "production unit", see Erik Kwakkel, "The Medieval Text Collections: A Codicological Typology Based on Single-Author Manuscripts," in Author, Reader, Book. Medieval Authorship in Theory and Practice, ed. Stephen Partridge and Erik Kwakkel (Toronto: University of Toronto Press, 2012), 56-79, at 60.

${ }^{11}$ See, e.g., Émile Lesne, Les livres, "Scriptoria" et Bibliothèques du commencement du VIIIe à la fin du XIe siècle (Lille: n.p., 1938), 358; Bernhard Bischoff, Latin Palaeography: Antiquity and the Middle Ages, trans. Dáibhí O Cróinín and David Ganz (Cambridge: Cambridge University Press, 1990), 41-42. Richard Gameson, "Anglo-Saxon Scribes and Scriptoria," in The Cambridge History of the Book in Britain, vol. 1, ed. Richard Gameson (Cambridge: Cambridge University Press, 2011), 94-120, at 107-110, gives a detailed assessment of the different kinds of collaboration and their rationales. For the problems of the concept of scriptorium, see David Ganz, "Can a Scriptorium Always Be Identified by Its Products", in Scriptorium: Wesen, Function Eigenheiten, ed. Andreas Nievergelt et al. (Munich: Bayerische Akademie der Wissenschaften, 2015), 51-62.

${ }^{12}$ The following list of studies of individual scriptoria which I have checked is hardly exhaustive: Maria Venturini, Vita ed attività dello "scriptorium" veronese nel secolo XI (Verona: Tipografica Veronese, 1930); Bernhard Bischoff and Josef Hofmann, Libri Sancti Kyliani: Die Würzburger Schreibschule und die Dombibliothek im VIII. und IX. Jahrhundert (Würzburg: F. Schöningh, 1952); Gerard I. Lieftinck, De librijen en scriptoria der Westvlaamse Cisterciënser-abdijen Ter Duinen en Ter Doest in de 12e en 13e eeuw en de betrekkingen tot het atelier van de kapittelschool van Sint Donatiaan te Brugge (Brussels: Paleis der Academiën, 1953); Bernhard Bischoff, "Die Kölner Nonenhandschriften und das Skriptorium vom Chelles," in Bernhard Bischoff, Mittelalterliche Studien, Vol. 1 (Stuttgart: Hiersemann, 1966), 16-34; id., Die südostdeutschen Schreibschulen und Bibliotheken in der Karolingerzeit, 2 vols. (Wiesbaden: Harrassowitz, 1974-1980); Jean Vezin, Les Scriptoria d'Angers au XIe siècle (Paris: H. Champion, 1974); Malcolm B. Parkes, The Scriptorium of Wearmouth-Jarrow (n.p.: n.p., 1982); Aliza Cohen-Mushlin, “The Twelfth-Century Scriptorium at Frankenthal," in Making the Medieval Book: Assessing the Evidence, ed. Linda L. Brownrigg (Los Altos Hills, CA: Anderson-Lovelace, 1990); 85-101, Aliza Cohen-Mushlin, A Medieval Scriptorium: 
Sancta Maria Magdalena de Frankendal, 2 vols. (Wiesbaden: Harrassowitz, 1990); Solange Michon, Le grand Passionnaire enluminé de Weissenau et son scriptorium autour de 1200 (Genève: Slatkine, 1990); William Noel, "The Division of Work in the Harley Psalter," in Making the Medieval Book: Techniques of Production ed. Linda L. Brownrigg (Los Altos Hills, CA: Anderson-Lovelace, 1995), 1-15; Francis Newton, The Scriptorium and Library at Monte Cassino, 1058-1105 (Cambridge: Cambridge University Press, 1999), esp. at 135-37; Alison I. Beach, Women as Scribes: Book Production and Monastic Reform in Twelfth-Century Bavaria (Cambridge: Cambridge University Press, 2004), esp. at 50-56 and 100-103; Aliza Cohen-Mushlin, Scriptoria in Medieval Saxony: St. Pancras in Hamersleben (Wiesbaden: Harrassowitz, 2004); Hartmut Hoffmann with Elmar Hochholzer, Schreibschulen des 10. und des 11. Jahrhunderts im Südwesten des Deutschen Reichs (Hannover: Hahnsche Buchhandlung, 2004); Mariapia Branchi, Lo scriptorium e la biblioteca di Nonantola (Nonantola: Centro studi storici nonantolan, 2011); Hartmut Hoffmann, Schreibschulen und Buchmalerei: Handschriften und Texte des 9.-11. Jahrhunderts (Hannover: Hahnsche Buchhandlung, 2012). Important discussion on the principles of collaboration in institutional scriptoria is found in Teresa Webber, Scribes and Scholars at Salisbury Cathedral c.1075-c.1125 (Oxford: Oxford University Press, 1992), 17 and 25.

${ }^{13}$ Aliza Cohen-Mushlin, "The Twelfth-Century Scriptorium at Frankenthal" and ead., Medieval scriptorium, 53-56; Sidney Tibbetts, "Praescriptiones, Student Scribes and the Carolingian Scriptorium," in La collaboration dans la production de l'écrit medieval: Actes du XIIIe colloque du Comité international de paléographie latine, ed. Herrad Spilling (Paris: École des Chartes, 2003), 24-35.

${ }^{14}$ E.g. Nancy Netzer, Cultural Interplay in the Eighth Century: The Trier Gospels and the Making of a Scriptorium at Echternach (Cambridge: Cambridge University Press, 1994), esp. at 4-11 and 34-41.

${ }^{15}$ Jean Vezin, “La répartition du travail dans les 'scriptoria' carolingiens," Journal des Savants, 1973: 212-27. See also T. A. M. Bishop, English Caroline Minuscule (Oxford: Clarendon Press, 1971), 6 and id., "Notes on Cambridge MSS, part viii," Transactions of the Cambridge Bibliographical Society 3.5 (1963): 420-3.

${ }^{16}$ An important exception is the discussion in Michael Gullick, "How Fast Did Scribes Write? Evidence from Romanesque Manuscripts," in Making the Medieval Book: Techniques of Production, ed. Linda L. Brownrigg (Los Altos Hills, CA: Anderson-Lovelace, 1995), 39-58, at 44-45.

${ }^{17}$ Berg, Studies in Tuscan Twelfth-century Illumination, 205-220; Nordenfalk, Codex Caesareus Upsaliensis, 136-7 and 147-8; Avril, “À quand remontent les premiers ateliers,” 36-44; Christopher De Hamel, Glossed Books of the Bible and the Origins of the Paris Booktrade (Woodbridge: D. S. Brewer, 1984); Patricia Danz 
Stirnemann, "Quelques bibliothèques princières et la production hors scriptorium au xiie siècle," Bulletin archéologique du CTHS, nouv. ser., fasc.17-18 (1984): 7-38; ead., "Où ont été fabriqués les livres de la glose ordinaire dans la première moitié du XIIe siècle?"; and Robert T. Chasson, "Méthodes de travail d'un scriptorium toscan au XIIe siècle: Changements et adaptations de modèles in mediis rebus," in Du scriptorium à l'atelier: Copistes et enlumineurs dans la conception du livre manuscrit au Moyen Âge (Turnhout: Brepols, 2011), 45-70.

${ }^{18}$ Very preliminary discussion of text scribes is found in De Hamel, Glossed Books of the Bible, 29.

${ }^{19}$ The following list makes no claims of exhaustiveness: Robert G. Calkins, Distribution of Labor: The Illuminators of the Hours of Catherine of Cleves and Their Workshop (Philadelphia: American Philosophical Society, 1979); John A. Holladay, "The Willehalm Master and His Colleagues: Collaborative Manuscript Decoration in Early-Fourteenth-Century Cologne," in Making the Medieval Book: Techniques of Production, 67-91; Susan Marti, “Zerteilt un verschieden geschmückt - Die arbeitsteilige Herstellung eines südwestdeutschen Psalters aus dem 13. Jahrhundert (Engelberg, Stiftsbibliothek, Cod. 61),” in La collaboration dans la production de l'écrit médiéval, 153-61; Zdenka Hledíkova, "Der Passional der Äbtissin Kungunde," in ibid., 169-182; Carmélia Opsomer, "Le scribe, l'enlumineur et le commanditaire: à propose des Tacuini sanitatis illustrés," in ibid., 183-92; Elena E. Rodríguez Díaz and Antonio Claret García Martínez, "La alta nobleza castellana y los libros: la colaboración en la traducción y copia de las Postillae de Nicolaus de Lyra (1420-1427)," in ibid., 201-21.

${ }^{20}$ Most notably, A. I. Doyle and Malcolm Parkes, "The Production of Copies of the Canterbury Tales and the Confessio Amantis in the Early Fifteenth Century," in Medieval Scribes, Manuscripts, and Libraries, ed. Malcolm B. Parkes and Andrew G. Watson (London: Scolar Press, 1978), 163-210. See also Jordi SanchezMarti, “The Scribe as Entrepreneur in Chetham's Library MS 8009," Bulletin of John Rylands University Library of Manchester 85:1 (2003): 13-22. The only study addressing the frequency of scribal collaboration of which I know is A. S. G. Edwards and Derek Pearsall, "The Manuscripts of the Major English Poetic Texts," in Jeremy Griffiths and Derek Pearsall (eds.), Book Production and Publishing in Britain, 1375-1475 (Cambridge: Cambridge University Press, 1989), 257-78, at 270.

${ }^{21}$ For the beginnings of the "bookshop theory", see Laura H. Loomis, "The Auchinleck Manuscript and a Possible London Bookshop of 1330-1340," PMLA 57 (Sept. 1942): 595-627; and Germaine Dempster, “Manly's Conception of the Early History of the Canterbury Tales," PMLA 61:2 [June 1946]: 411; for its criticism, see A. Shonk, "A Study of the Auchinleck Manuscript: Bookmen and Bookmaking in the Early 
Fourteenth Century," Speculum 60 [January 1985]: 71-91, and for what appears the present scholarly consensus Malcolm Parkes, Their Hands Before Our Eyes (Aldershot: Ashgate, 2008), 51-53; C. Paul Christianson, “The Rise of London's Book-trade," in The Cambridge History of the Book in Britain, vol. 3, ed. Lotte Hellinga and J. B. Trapp (Cambridge: Cambridge University Press, 1999), 128-147, at 130; and Julia Boffey and A. S. G. Edwards, "Vernacular Literature and Its Readership: II Middle English Literary Writings, 1150-1400," in The Cambridge History of the Book in Britain, vol. 2, ed. R. Thomson and N. Morgan (Cambridge: Cambridge University Press, 2008), 380-96, at 388.

${ }^{22}$ The main study remains Vezin, “La répartition du travail”. See also Jean Vezin, “'Quaderni simul ligati”: Recherches sur les manuscrits en cahiers," in Of the Making of Books: Medieval Manuscripts, their Scribes and Readers, ed. P. R. Robinson and Rivkah Zim (Aldershot: Ashgate, 1997), 64-70, at 69-70; Bischoff, Latin Palaeography, 41-42 and, for some corrections to Vezin, Vladimir I. Mazhuga, “Über die Arbeitsteilun karolingisher Schreiber," in La collaboration dans la production de l'écrit médiéval, 9-24.

${ }^{23}$ See, e.g., Paola Supino Martini, "Sul metodo paleografico: formulazione di problemi per una discussione," Scrittura e civiltà 19 [1995]: 16, and Julia Marwin, The Construction of Vernacular History in the AngloNorman Prose Brut Chronicle: The Manuscript Culture of Late Medieval England (Woodbrige: York Medieval Press, 2017), 133.

${ }^{24}$ The pecia system used in these cities has likewise attracted scholarly attention disproportionate to the quantity of manuscripts actually produced using it, a point well made in David D'Avray, "Printing, Mass Communication, and Religious Reformation: The Middle Ages and After," in The Uses of Script and Print, ed. Crick and Walsham, 50-70, at 53.

${ }^{25}$ Jean Vezin ("La répartition du travail," p. 3) himself wrote about how quire-by-quire copying relates to the production of the ateliers universitaires (a vague concept in itself) in a dangerously ambiguous way: "Ces pratiques [Carolingian quire-by-quire copying] annoncent en quelque sorte, d'une manière bien rudimentaire, le procèdé de la pecia utilisé plus tard dans les ateliers universitaires pour multiplier rapidement les copies tirées d'une même exemplar." ["These practices announce in some very elementary way the pecia procedure used later in university ateliers to multiply copies rapidly using the same exemplar."' Likewise, Maria Luisa Agati, Il libro manoscritto da oriente a occidente: Per una codicologia comparata [Rome: "Erma" di Bretschneider, 2009], 255-60, comes close to equating the pecia system of exemplar distribution with "mass-production" by quire-by-quire copying. 
${ }^{26}$ Because of the limitations of the data supplied by the catalogues, it has not been possible to differentiate between scribes who copy to set an example or write just a brief passage and the main scribes, as is done in admirable detail in Cohen-Muslin, A Medieval Scriptorium, vol. 1, 53 and table 3 at 80-81.

${ }^{27}$ See also Webber, Scribes and Scholars, 10. This is an assumption widely shared but seldom explicated, perhaps because it appears self-evident.

${ }^{28}$ These are described in Albert Brückner, Scriptoria Medii Aevi Helvetica, 2 vols. (Geneva: Roto-Sadag, 193537).

${ }^{29}$ Three items from this period have been excluded since they contain fewer than 9 folios (Brückner's 97.5, 97.6, and 112) and ten because the information on the scribes is inadequate (Brückner's 5, 18, 66, 91, 97.5, 97.6, 97.7, 108, 109, and 110).

${ }^{30}$ Bischoff, Die südostdeutschen Schreibschulen.

${ }^{31}$ Twenty units - all fragments of four or fewer folios - have been excluded because of their shortness (numbers $4,15,17,27,43,47,48,49,58,59,60,61,66,82,83,100,101,102,103$, and 110 in Bischoff's list) and one (54) because the data on the scribes is not precise.

${ }^{32}$ Jean Dufour, La Bibliothèque et le Scriptorium de Moissac (Geneva and Paris: Droz, 1972).

${ }^{33}$ MSS 50, 71, 77, 81, 87, and 96 in Dufour's list.

${ }^{34}$ These are MSS 72 (Paris, Bibliothèque nationale de France, MS lat. 2627) and 100 (Paris, BnF, MS lat. 17002) in Dufour's list.

${ }^{35}$ MSS 80 and 92 in Dufour's list.

${ }^{36}$ Webber, Scribes and Scholars.

${ }^{37}$ There are ten entities with eight or fewer folios (MSS 10, 44, 46, 103, 104, 115, 126, 129, 144, and 148 in Webber's list).

${ }^{38}$ The institution had a previous existence as a house of Augustinian Canons, founded in 1127.

${ }^{39}$ Donatella Frioli, Lo Scriptorium e la biblioteca del monastero cisterciense di Aldersbach (Spoleto: Centro italiano di studi sull'alto medioevo, 1990), 37-94.

${ }^{40}$ Just one entity has been excluded because of its brevity (MS 34.2 in Frioli’s list).

${ }^{41}$ Gullick, "How fast did scribes write?," 44-48.

${ }^{42}$ The lists are edited in K. Dengler-Schreiber, Scriptorium und Bibliothek des Klosters Michelsberg in Bamberg von den Anfängen bis 1150 (Graz: Akademische Druck- und Verlagsanstalt, 1979), 196-205. 
${ }^{43}$ Bamberg, Staatsbibliothek, Patr 112, Bibl 52, Bibl 53, Bibl 55, Patr 85, Patr 85, Bibl 116, described in Dengler-Schreiber, Scriptorium und Bibliothek.

${ }^{44}$ There are 42 manuscripts for which Dengler-Schreiber, Scriptorium und Bibliothek, supplies enough data on the scribes. Five manuscripts are either fragments or not examined in enough detail.

${ }^{45}$ Dufour, La bibliothèque, 36-37.

${ }^{46}$ See Cohen-Mushlin, A Medieval Scriptorium, vol. 1, Table 3, at pp. 80-81. To make the data comparable, I have counted together Cohen-Mushlin's "text scribes," "exemplum scribes," and "interpolators," since they all participated into the making of what was the main text in the final product, and must have worked (almost entirely) sequentially.

${ }^{47}$ Webber, Scribes and Scholars, 10.

${ }^{48}$ This is the average percentage of the centers (i.e., the single-scribe copy percentages of the centers summed up and divided by the number of centers), not the average percentage of single-scribe copies of all the manuscripts examined as a single data set.

${ }^{49}$ See footnote 21 above.

${ }^{50}$ Vespasiano Da Bisticci, who according to his own report supplied Cosimo di Medici with 200 books which were copied by 45 scribes over 22 months (see Vespasiano Da Bisticci, Vite di uomini illustri del secolo XV, ed. Angelo Mai \& Adolfo Bartoli (Firenze: Barbéra, Bianchi, 1859), 255), would be one choice for such an examination, but there is no catalogue of the many manuscripts associated with him. For Vespasiano, see Albinia C. De La Mare, "Vespasiano da Bisticci as Producer of Classical Manuscripts in Fifteenth-Century Florence," in Medieval Manuscripts of the Latin Classics: Production and Use, ed. Claudine A. ChavannesMazel and Margaret M. Smith (Los Altos Hills, CA: Anderson-Lovelace, 1996), 166-207.

${ }^{51}$ E.g. Elisabetta Caldelli, Copisti a Roma nel Quattrocento (Roma: Viella, 2006).

${ }^{52}$ Large numbers of books can admittedly be associated with some exceptional scribes. For instance, A. De La Mare reports that over 70 manuscripts can be attributed to Piero, parish priest of Ripoli (De La Mare,

"Vespasiano da Bisticci as producer of classical manuscripts", n. 43), but again, there is no catalogue available and the construction of a data set would require substantial original research.

${ }^{53}$ For instance, Robert W. Hanning, “The Audience as Co-creator of the First Chivalric Romances," Yearbook of English Studies 11 (1981): 1-28.

${ }^{54}$ Marco Cursi, Il Decamero: Scritture, scriventi, lettori: storia di un testo (Rome: Viella, 2007), 74-80. 
${ }^{55}$ See Les Manuscrits de Chrétien de Troyes: The Manuscripts of Chrétien de Troyes, ed. Keith Busby, Terry Nixon, Alison Stones, and Lori Walters, 2 vols. (Amsterdam and Atlanta: Rodopi, 1993), vol. 2, descriptions of individual manuscripts and the table of former owners at $90-91$.

${ }^{56}$ Corpus of British Medieval Library Catalogues 13. St Augustine's Abbey, Canterbury, ed. B. C. BarkerBenfield, (London: British Library and British Academy, 2008), 1:5.

${ }^{57}$ Manuscripts with French texts (sometimes in combination with Latin ones): BA1.39, 224, 312, 312, 486, 687, $758,806,857,979,1246,1267,1504,1505,1506,1507,1508,1509,1510,1511,1512,1513,1516,1517$, $1518,1519,1520,1521,1522,1523,1524,1525,1526,1528,1529,1530,1531,1532,1533,1534,1535,1538$, 1548. Middle English: BA1.991 (Chaucer's translation of Boethius) and BA1.1536 (Ayenbite of Inwit).

${ }^{58}$ The romances: BA1.1506, 1516, 1517, 1518, 1519, 1520, 1521, 1522c, 1523, 1524a, 1525, 1526, 1528, 1529, 1530, 1533, and 1534. Owned by Thomas Arnold (fl. 1368-1407/8): BA1.1518, 1526, 1528, 1529, 1530, 1533, and 1534 .

${ }^{59}$ On medieval library catalogues, see Richard Sharpe, "Library Catalogues and Indexes," in The Cambridge History of the Book in Britain, vol. 2: 1100-1400, ed. N. J. Morgan and R. M. Thomson (Cambridge: Cambridge University Press, 2008), 195-218 and id., "The Medieval Librarian," in A History of Libraries in Britain and Ireland, vol. 1, From the Beginnings to 1640, ed. Teresa Webber and E. S. Leedham-Green (Cambridge: Cambridge University Press, 2006), 218-41.

${ }^{60}$ There is ample evidence for the use of vernacular spiritual texts especially in nunneries, where the expectation of Latin education was not necessarily set as high. See for instance Virginia R. Bainbridge, "Syon Abbey: Women and Learning c.1415-1600", in Syon Abbey and its Books: Reading, Writing and Religion c.1400-1700, ed. E. A. Jones and Alexandra Walsham (Woodbridge: Boydell Press, 2010), 82-103; and Ville Walta, Libraries, Manuscripts and Book Culture in Vadstena Abbey (Unpublished dissertation, University of Helsinki, 2014), 174-182 and 273-279. For Augustinian canons' use and possession of vernacular (mostly religious) texts, see Ralph Hanna, "Augustinian Canons and Middle English Literature," in The English Medieval Book, ed. A. S. G. Edwards, Vincent A. Gillespie, and Ralph Hanna (London: British Library, 2000), 27-44.

${ }^{61}$ Richard Sharpe, “Monastic Reading at Thorney Abbey, 1324-1347," Traditio 60 (2005): 243-78, suggests that official and private practices of reading may have differed in a monastery.

${ }^{62}$ Volume 2 contains descriptions of all the manuscripts, but volume 1 contains also a number of articles which are in effect catalogues in their own right: Terry Nixon, "Romance Collections and the Manuscripts of Chrétien de Troyes," 17-26; Stewart Gregory and Claude Lutrell, "The Manuscripts of Cligés," 67-96; and Françoise 
Gasparri, Geneviève Hasenohr, and Christine Ruby, "De l'écriture à la lecture: refléxion sur les manusripts d'Erec et Enide," 97-148. The basic descriptions are found in Les Manuscrits de Chrétien de Troyes, 1:1-85.

${ }^{63}$ The only instance of different interpretations over the number of scribes concerns Paris, BnF, MS fr. 375, views dividing over whether there are five or six hands.

${ }^{64}$ Marisa Boschi Rotiroti, Codicologia trecentesca della Commedia (Roma: Viella, 2004).

${ }^{65}$ Many manuscripts of Dante contain a commentary, and that was often copied by a different scribe. As always, I have considered only the scribes of the main text.

${ }^{66}$ Edwards and Pearsall, "The Manuscripts of the Major English Poetic Texts". I include only the lengthiest texts in this comparison. The others examined by Griffiths and Pearsall are shorter than 10,000 verses (Canterbury Tales is c. 24,400), and thus more likely to have been copied by a single scribe. Confessio Amantis, Troy Book, and Fall of Princes are all longer than the Canterbury Tales.

${ }^{67}$ See Pearsall and Edwards, “The Manuscripts of the Major English Poetic Texts”, 271. Their data sources were John M. Manly and Edith Rickert, The Text of the Canterbury Tales Studied on the Basis of All Known Manuscripts (Chicago: University of Chicago Press, 1940), 1:29-544; The English Works of John Gower, ed. G. C. Macaulay (London : Published for the Early English Text Society by Kegan Paul, Trench, Trübner, 1900), 1:cxxxviii-clxv; Lydgate's Troy Book, ed. Henry Bergen, part 4, Early English Text Society ES, 126 (1935); 154; Lydgate's Fall of Princes, ed. Henry Bergen, Early English Text Society, Extra Series 126 (London: published for the Early English Text Society by Humphrey Milford, Oxford University Press, 1927), 4:11-105. ${ }^{68}$ M. C. Seymour, A Catalogue of Chaucer Manuscripts, 2 vols. (Aldershot: Scolar Press, 1997). On the shortcomings of Seymour's Catalogue, see Hugh White, Review of English Studies 50 (1999): 220-21 and Stephen Partridge, Speculum 77 (2002): 1393-95. I have not personally examined any of the Chaucer manuscripts.

${ }^{69}$ Manly and Rickert, The Text of the Canterbury Tales.

${ }^{70}$ See Cursi, Il Decameron, 76-80. Cursi does not discuss the possibility of institutional origin.

${ }^{71}$ There are seven with two hands, two with three, and one with four. In all these, one scribe only writes one stint.

${ }^{72}$ British Library, Add. MS 25 718. See Seymour, A Catalogue of Chaucer MSS, vol. 2, 99.

${ }^{73}$ Hunterian Museum, U.1.1 (197). See Seymour, A Catalogue of Chaucer MSS, vol. $2,83$.

${ }^{74}$ British Library, Harley 7333, ff. 33-119. See Seymour, A Catalogue of Chaucer MSS, vol. 2, 124, and vol. 1, 23. In vol. 2, Seymour suggests the manuscript would have been written on private commission there, and 
points the reader to vol. 1, where no evidence on the commission is however given. For the evidence connecting the manuscript to St. Mary de Pratis (although not suggesting private commission), see Manly and Rickert, Text of the Canterbury Tales, 1:214-15. See as well Michael Johnston, "Two Leicestershire Romance Codices: Cambridge, University Library MS Ff.2.38 and Oxford, Bodleian Library MS Ashmole 61," Journal of the Early Book Society 15 (2012): 88.

${ }^{75}$ British Library, Egerton 2726. In this manuscript both scribes write two stints, i.e., there are much fewer changes than in the two others mentioned in this category.

${ }^{76}$ The first agreement of a commission from Paris of which we know, the making of a complete glossed Bible for Gui, bishop of Clermont, specifies the text is to be copied in one hand. See Rouse and Rouse, Manuscripts and Their Makers, $52 \mathrm{ff}$., and in particular the discussion about de una manu at 64-65. Five volumes of the Bible survive, and they are actually by three different scribes, but (and this is important for the present argument) we always see just one hand in one volume.

${ }^{77}$ Fabio Troncarelli, Boethiana aetas: Modelli grafici e fortuna manoscritta della Consolatio Philosophie tra Ie IX e XII secolo (Alessandria: Edizioni dell'Orso, 1987).

${ }^{78}$ Günter Glauche, Schullektüre im Mittelalter: Entstehung und Wandlungen des Lektürkanons bis 1200 nach den Quellen dargestelt (München: Arbeo-Ges., 1970), 13-14, 29, and idem, "Die rolle der schulautoren im Unterricht", in La Scuola nell'Occidente latino dell'alto medioevo, vol. 2 (Spoleto: Centro Italiano di Studi sull'Alto Medioevo, 1972), 618-638, at 624-628

${ }^{79}$ See Pierre Courelle, La Consolation de Philosophie dans la tradition littéraire (Paris: Études augustiniennes, 1967), 241-315 and Glauche, Schüllekture, 54-56

${ }^{80}$ For numbers of manuscripts, see Birger Munk Olsen, L'Étude des auteurs classiques latins aux XI et XII siècles, I-IV (Paris: Centre National de la Recherche Scientifique, 1982-2014), vol. 4.2, table 3, at 24-30. The physical characteristics of the manuscripts suggest they found their use in scholarly contexts. Out of the 133 manuscripts, 83 contain glosses. Their average size is $344 \mathrm{~cm} 2$ and median size just $311 \mathrm{~cm} 2$, i.e., they are

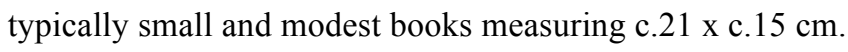

${ }^{81}$ This figure is based on the list of manuscripts published by Birger Munk Olsen (L'étude des auteurs classiques latins, vols. 2 and 4.2), revised according to my own study of the manuscripts.

${ }^{82}$ The selection has been based on practical criteria, i.e., which libraries it has been possible to visit. I have so far studied all manuscripts in British libraries, Bibliothèque nationale de France, the Vatican Library, and the Staatsbibliothek zu Berlin, in addition to those available on line. The manuscripts examined are listed below, 
with the number of scribes in brackets after each shelfmark. The expression " $3+$ " means three or more scribes, as elsewhere in this article. Berlin, Deutsche Staatsbibliothek, MSS Phill. 1901 (2), Phill. 1902 (3+), lat. 4:o 907 (2), Cambridge, Pembroke College, MS 114 (3+), Cambridge, University Library, MS Ii.6.20 (1), Kobenhavn, Det kongelige Bibliotek, MSS Fabricius 25 2:o (1), Fabricius 83 8:o (1), London, British Library, MSS Add. 11 944 (1), Add. 35109 (1), Arundel 234 (1), Harley 2643 (1), Harley 2643 (1), Harley 5412 (1), München, Bayerische Staatsbibliothek, Clm 4559-I (1), Clm 4603 (1), Clm 14477-I (2), Clm 14515-I (3+), Clm 14685 (3+), Clm 19472-II (2), Oxford, Bodleian Library, MSS Rawlinson G.43 (3+), Rawlinson G.44 (3+), Paris, Bibliothèque nationale de France, MSS lat. 5749 (3+), lat. 5750 (1), lat. 5751-I (1), lat. 5751-II (2), lat. 6086 (2), lat. 6087 (3+), lat. 6088 (1), lat. 6253 (1), Vatican City, Biblioteca Apostolica Vaticana, MSS Ottob. Lat. 1648 (1), Ottob. Lat. 1843 (3+), Pal. Lat. 862-IV (1), Pal. Lat. 883 (2), Pal. Lat. 887 (1), Pal. lat. 888-I (1), Reg. lat. 571-V (1), Reg. lat. 686 (2), Reg. lat. 814 (2), Reg. lat. 1406 (1), Reg. lat. 1574-II (1), Rossi 508 (1), Vat. lat. 1833 (1), Vat. lat. 1834 (1), Vat. lat. 1904-II (1), Vat. lat. 2955-I (3+), Vat. lat. 3326 (2), Vat. lat. 3327 (1), Vat. lat. $3328(3+)$, Vat. lat. 5345 (2), Vat. lat. 6272 (1), Vat. lat. 9991-I (1).

${ }^{83}$ Rodney M. Thomson, Catalogue of Medieval Manuscripts of Latin Commentaries on Aristotle in British Libraries, vol. 1., Oxford (Turnhout: Brepols, 2011).

${ }^{84}$ Rodney M. Thomson, Catalogue of the Manuscripts of Lincoln Cathedral Chapter Library (Woodbridge, Suffolk; Wolfeboro, NH: Published on behalf of the Dean and Chapter of Lincoln by D.S. Brewer, 1989); id., A Descriptive Catalogue of the Medieval Manuscripts of Corpus Christi College Oxford (Cambridge: Published for Corpus Christi College Oxford by D. S. Brewer, 2011), id.; A Descriptive Catalogue of the Medieval Manuscripts in the Library of Peterhouse, Cambridge (Woodbridge, Suffolk; Rochester, NY: Published for Peterhouse, Cambridge by D. S. Brewer, 2016); Nigel Guy Wilson, A Descriptive Catalogue of the Medieval Manuscripts of Merton College, Oxford (Cambridge: Published for Merton College, Oxford, by D. S. Brewer, 2009); Rodney M. Thomson and Michael Gullick, A Descriptive Catalogue of the Medieval Manuscripts in Worcester Cathedral Library (Rochester, NY: Published on behalf of the dean and chapter of Worcester Cathedral by D. S. Brewer, 2001).

${ }^{85}$ George Lacombe, Aristoteles latinus, pars prior (Bruges and Paris: Desclée de Brouwer, 1937).

${ }^{86}$ Félix Olivier-Martin, “Monseigneur George L. Lacombe,” Bibliothèque de l’École des Chartes 96 (1935): $179-84$. 
${ }^{87}$ See Lacombe, Aristoteles Latinus, 1:43-45. The texts pass under various names. Lacombe identifies them as Predicamenta (a.k.a. Categoriae), Periermenias (a.k.a. De interpretatione), Boetius in Isagogen, Boetius in Categorias, and Boetius in Periermenias.

${ }^{88}$ See Lacombe, Aristoteles Latinus, 1:45-49.

${ }^{89}$ Six manuscripts contain only texts of the logica vetus, seven contain only texts of the logica nova, and two contain texts of both.

${ }^{90}$ The rise in the proportion of small-format books may in part reflect the fact that they survive less well than large ones, but for other explanations see Jaakko Tahkokallio, "The Classicisation of the Latin Curriculum and 'The Renaissance of the Twelfth Century': A Quantitative Study of the Codicological Evidence," Viator 46.2 (2015): $129-153$, at $138-9$ and $150-1$.

${ }^{91}$ One copy of Sallust (British Library, Add. 35109) has a famous colophon indicating it was copied by "Milus Notarius" in 1192. This has often been taken as a sign of it being a personal copy, but a notary could have been employed to make a copy of the book for another person.

${ }^{92}$ For examples of student scribes, some of whom were also monks or friars, collaborating in such settings, see Rodney Thomson, "Monastic and Cathedral Book Production," in The Cambridge History of the Book in Britain, 2:136-67, at 165, and Thomson and Gullick, Catalogue of the Medieval Manuscripts in Worcester Cathedral, $\mathrm{xxv}-\mathrm{xxx}$ and $\mathrm{xxxv}-\mathrm{xxxvii}$.

${ }^{93}$ Parkes, Their Hands, 51-53. See also id., "Patterns of Scribal Activity and Revisions of the Text in Early Copies of Works by John Gower," in New Science out of Old Books, ed. Richard Beadle and A. J. Piper (Aldershot: Scolar Press, 1995), 81-121, esp. at 81-82 and 94-98.

${ }^{94}$ According to Buringh's estimate (Manuscript Production in the Latin West, 99, table 3.1), there survive c. 1,300,000 manuscripts from the medieval Latin West.

${ }^{95}$ Michael Johnston and Michael Van Dussen, "Introduction: Manuscripts and Cultural History," in The Medieval Manuscript Book: Cultural Approaches, ed. Michael Johnston and Michael Van Dussen (Cambridge: Cambridge University Press, 2015), 1-16, at 1.

${ }^{96}$ T. J. Brown, "Latin Palaeography since Traube”, Transactions of the Cambridge Bibliographical Society 3 , No. 5 (1963): 361-81, well documents the development of the discipline in the first half of the twentieth century, and indeed the research agenda it lays out remains relevant in many ways today.

${ }^{97}$ See in particular Carla Bozzolo and Ezio Ornato, Pour une histoire du livre manuscrit au Moyen Âge: Trois essais de codicologie quantitative (Paris: CNRS, 1980). Much relevant work was also published in Scrittura e 
civiltà over the course of its existence (1977-2001). Of more recent studies, in addition to the Italian ones used as sources of data in this study (Cursi, Boschi, Rotiroti) one may draw attention to the research being carried out by scholars at LAMOP (Laboratoire de Médiévistique Occidentale de Paris), e.g., Chiara Ruzzier, "The Miniaturisation of Bible Manuscripts in the 13th century: A Comparative Study", in Form and Function in the Late Medieval Bible, ed. Laura Light and Eyal Poleg (Leiden-Boston: Brill, 2013), 105-25; and Laura Albiero's yet unpublished work on portable breviaries.

${ }^{98}$ For example, the medieval volumes (1-3) of The Cambridge History of the Book in Britain bring together much essential work in this tradition.

${ }^{99}$ One could see the feeding of such tendencies as the one downside of the approach exemplified in Christopher De Hamel's hugely enjoyable best seller Meetings with Remarkable Manuscripts (London: Allen Lane, 2016). ${ }^{100}$ The Guiot MS = Paris, BNF, fr. 794; Hengwrt Chaucer = Aberystwyth, NLW, Peniarth MS 392D.

${ }^{101}$ Major palaeographical initiatives include the King's College London hosted Digipal (http://www.digipal.eu/) and the CLAMM initiative, hosted by IRHT Paris (http://clamm.irht.cnrs.fr/). The EU-funded READ initiative (Recognition and Enrichment of Archival Documents, https://cordis.europa.eu/project/ren/198756 en.html) has recently made promising progress. On digital stemmatology, see e.g. T. Roos and T. Heikkilä, "Evaluating Methods for Computer-assisted Stemmatology Using Artificial Benchmark Data Sets," Literary and Linguistic Computing 24 (2009): 417-33 and Marina Buzzoni et al., "Open Versus Closed Recensions (Pasquali): Pros and Cons of Some Methods for Computer-assisted Stemmatology," Digital Scholarship in the Humanities 31.3 (2016): 652-69. For a selection of articles discussing each of these fields, see Analysis of Ancient and Medieval Texts and Manuscripts: Digital Approaches, ed. Tara Andrews and Caroline Macé (Turnhout: Brepols, 2014). ${ }^{102}$ Peter Stokes, "Digital Approaches to Palaeography and Book History: Some Challenges, Present and Future," Frontiers in Digital Humanities 2:5 (2015). doi:10.3389/fdigh.2015.00005; Tal Hassner et al., “Computation and Palaeography: Potentials and Limits", Dagstuhl Manifestos 2 (2013): 14-35.

${ }^{103}$ Jan M. Ziolkowski, “From Didactic Poetry to Bestselling Textbooks," in Calliope's Classroom: Studies in Didactic Poetry from Antiquity to the Renaissance, ed. Annette Harder, Alasdair A. MacDonald, and Gerrit J. Reinink (Leuven: Peeters, 2007), 221-43, at 239. 